University of Pennsylvania Carey Law School

Penn Law: Legal Scholarship Repository

Faculty Scholarship at Penn Law

$1-1-2011$

\title{
Advantaging Aggressors: Justice \& Deterrence in International Law
}

Paul H. Robinson

University of Pennsylvania Carey Law School

Adil Ahmad Haque

Rutgers University - Newark

Follow this and additional works at: https://scholarship.law.upenn.edu/faculty_scholarship

Part of the Criminal Law Commons, Human Rights Law Commons, International Law Commons, International Relations Commons, Law and Society Commons, Military, War, and Peace Commons, National Security Law Commons, and the Public Policy Commons

\section{Repository Citation}

Robinson, Paul H. and Haque, Adil Ahmad, "Advantaging Aggressors: Justice \& Deterrence in International Law" (2011). Faculty Scholarship at Penn Law. 297.

https://scholarship.law.upenn.edu/faculty_scholarship/297

This Article is brought to you for free and open access by Penn Law: Legal Scholarship Repository. It has been accepted for inclusion in Faculty Scholarship at Penn Law by an authorized administrator of Penn Law: Legal Scholarship Repository. For more information, please contact PennlawIR@law.upenn.edu. 


\title{
ARTICLE \\ Advantaging Aggressors: Justice \& Deterrence in International Law

\author{
Paul H. Robinson* \& Adil Ahmad Haque**
}

\begin{abstract}
Current international law imposes limitations on the use of force to defend against unlawful aggression that improperly advantage unlawful aggressors and disadvantage their victims. The Article gives examples of such rules, governing a variety of situations, showing how clearly unjust they can be. No domestic criminal law system would tolerate their use.

There are good practical reasons why international law should care that its rules are perceived as unjust. Given the lack of an effective international law enforcement mechanism, compliance depends to a large degree upon the moral authority with which international law speaks. Compliance is less likely when its rules are perceived as obviously unjust. This common sense perspective is supported by social science research showing the importance of law's moral credibility in gaining assistance and compliance, in reducing resistance and subversion, and in helping to shape shared norms. The current practice of victim states ignoring legal limitations, with studied indifference to such "violations" by the international community, only legitimizes and habituates law-breaking, further undermining international law's moral credibility.
\end{abstract}

One important opportunity for reforming international law is currently being squandered. The Assembly of State Parties to the International Criminal Court has recently approved a resolution defining the international crime of aggression. However, rather than confront international law's existing problems, the drafters

* Colin S. Diver Professor of Law, University of Pennsylvania. The authors would like to thank William Burke-White, Margaret DeGuzman, Robert Sloane, Deborah Pearlstein, and Lori Damrosch, as well as workshop participants at the University of Pennsylvania Law School and Temple Law School for their comments, and Nicole Barna for her invaluable research assistance.

** Associate Professor of Law, Rutgers School of Law - Newark. 
compounded them by imposing individual criminal liability on leaders of victim states who authorize defensive force in violation of flawed current law.

Fortunately, the resolution will not go into effect until 2017 at the earliest. There is still time to change course.

\section{Introduction}

The use of force by and against states remains a persistent feature of international affairs. NATO forces based in Afghanistan target Taliban fighters based in Pakistan, while Turkish jets strike Kurdish separatists in Iraq, Columbian soldiers attack armed groups in Ecuador, Israeli commandos enter Gaza in their ongoing conflict with Hamas, and various naval powers retaliate against pirates docked in Somalia.

As U.S. President Barack Obama observed in his speech accepting the Nobel Peace Prize, "[t]here will be times when nations - acting individually or in concert - will find the use of force not only necessary but morally justified." 1 To its credit, international law permits states to use force when force is most clearly necessary and morally justified, namely in defense against an armed attack by another state. However, this article argues that international law restricts the use of defensive force by states in ways that are both unjust to victim states and damaging to the international system.

Part I briefly compares the functions of international law and criminal law rules governing the use of force. Although the former rules are directed toward states and the latter rules are directed toward individuals, this difference may be overshadowed by the fact that at root both regimes seek justice and stability. Part II offers a criminal law-based critique of several international law use of force rules that seem to produce strikingly unjust results, typically by imposing unjustified limitations on the use of defensive force. For example, according to the International Court of Justice (ICJ), states may not use defensive force against unlawful armed aggression that is limited in its scale and effects, or (it seems) against non-state actors using another state as a base of operations for unlawful aggression. One might be inclined to defer to existing international law rules governing the use of force on the assumption that they are the product of rich experience born of a long history. From the perspective of a criminal law scholar, however, these international law rules seem difficult to defend.

${ }^{1}$ Obama: 'Peace Requires Responsibility,' CNN (Dec. 10, 2009),

http://www.cnn.com/2009/POLITICS/12/10/obama.transcript/index.html. 
Part III argues that, for good practical reasons, international law ought to care whether its rules are perceived as unjust by the international community. Given the lack of an effective international law enforcement mechanism, compliance depends to a large degree upon the moral authority with which international law speaks. Compliance is less likely when its rules are perceived as obviously unjust. This common sense perspective is supported by social science research showing the importance of law's moral credibility in gaining assistance and compliance, in reducing resistance and subversion, and in helping to shape shared norms. The current practice of victim states ignoring legal limitations, with studied indifference to such "violations" by the international community, only legitimizes and habituates law-breaking, further undermining international law's normative influence. Importantly, Part III refutes two potential objections to our approach: that moral intuitions regarding interpersonal violence do not apply to international violence; and that international law ought to sacrifice justice for the sake of peace.

Part IV examines interpretations of international law that would narrow the gap between legal rules and moral intuitions regarding defensive force. Reliance on these revisionist interpretations of international law may be a useful temporary measure, but it does not offer a comprehensive solution because the gap can be narrowed but not closed by reinterpretation alone. Given the flaws in international law's foundational texts, in particular in Article 51 of the UN Charter, international law must be substantially reformed in order to achieve consistency with shared intuitions of justice. We offer a specific proposal that permits the use of necessary and proportionate defensive force to prevent any use of armed force by states or non-state actors.

The first parts of the Article build on the analogies between international law and criminal law. Part V, by contrast, explains why the two bodies of law should operate differently in some contexts. Most fundamentally, international law lacks the law enforcement mechanisms found in domestic criminal justice systems. This difference demands a different set of rules governing responses to unlawful aggression, imposing fewer limitations on the use of defensive force than under ordinary criminal law, not more limitations, since generally only such defensive force will in fact deter aggression.

Part VI gives a series of examples of international law's improper limitations on the use of force in responses to unlawful aggression, which have the unfortunate effect of promoting aggression and instability by undermining 
effective deterrence. For example, according to the ICJ's past rulings, it seems that victim states may not use force against a state that supports but does not control armed groups that launch unlawful armed attacks; or against an unlawful aggressor between discrete attacks; or against military objectives that are not the source of a prior attack; or in response to a past attack in order to deter future attacks.

Part VII suggests interpretations of international law that would avoid these improper limitations and allow greater decentralized deterrence of aggression by individual states. Again, however, such shifts in interpretation are at best stopgap measures. Ultimately, the flawed nature of international law's foundational texts means that reform is required. A specific proposal is offered that permits the use of necessary and proportionate deterrent force under strict limitations.

One important opportunity for reforming international law is currently being squandered. The Assembly of State Parties to the International Criminal Court (ICC) has recently approved a resolution defining the international crime of aggression. ${ }^{2}$ Rather than confront international law's existing problems, however, the drafters compound them by imposing individual criminal liability on leaders of victim states who authorize defensive force in violation of flawed current law. Fortunately, the resolution will not go into effect until 2017 at the earliest, when the States Parties may formally amend the Rome Statute, which establishes and limits the ICC's jurisdiction. ${ }^{3}$ There is still time to change course.

\section{Functional Similarities Between International Law and Domestic Criminal Law}

International laws governing the use of force by nations and domestic criminal laws governing use of force by individuals respond to similar challenges. One goal in each instance is to maintain sufficient order within a given community so that its members, who must inevitably interact with one another, may mutually coexist. The use of force by one member can injure others and thereby undermine the stability of the community. At the same time, the use of force is sometimes necessary to advance larger interests, as when it is used to restrain or avoid the violation of rules important for order and stability, including rules against the unjustified use of force. In other words, sometimes the only way

${ }^{2}$ Int'l Criminal Court [ICC], Assembly of States Parties, The Crime of Aggression, Annex I, art. 8 bis, ICG Doc. RC/Res.6 (advance version June 28, 2010) (hereinafter "Aggression Resolution").

${ }^{3} I d$. art. 15 bis 93 . 
to avoid unlawful, destabilizing force is to use force. But without clear and agreedupon rules on when the use of force is permitted, every use of force, even when motivated by the desire to bring stability, can create instability.

One could make similar observations with regard to the goal of avoiding injustice. Whether on the world stage among states or on the societal stage among individuals, sometimes defensive force is the only effective means by which unjustified aggression can be avoided. A just law requires a clear statement of when force is justified and when it is condemnable, and a just system authorizes the use of force when necessary to protect against unlawful aggression.

Given the similar challenges faced by domestic and international law, it should be no surprise that some important similarities exist between international law rules and criminal law rules regarding the use of force. For example, both international law and criminal law permit defenders to use only the force necessary for effective defense; an unlawful attack does not authorize an unlimited response. Such a "necessary-force" limitation seems to advance the goals of stability and justice in both national and international contexts.

Despite the similar functions of use of force rules in the international and domestic contexts, Part II demonstrates that international law has failed to follow many of the hard-learned lessons of criminal law. A variety of international law limitations on the use of force conflict with criminal law use of force rules. Indeed, some of the limitations imposed by international law on the use of defensive force have been expressly considered and rejected in criminal law. ${ }^{4}$ Our analysis suggests that they ought to be rejected in international law as well.

II. International Law Limitations on the Use of Force that Conflict with Criminal Law Principles of Justice

Prior to the $20^{\text {th }}$ Century, the few legal rules that governed the use of force by nations were derived solely from the norms of customary international law as they arose from the reflective convergence of state practice and opinion. Perhaps because customary international law was intended to operate in the absence of a centralized enforcement authority, its constraints on the use of force were limited to general principles, such as requiring necessity and proportionality in the use of defensive force, which enjoyed intuitive moral credibility among a wide range of

${ }^{4}$ See, e.g., text accompanying notes 22, 46, \& 53-54 infra. 
people and states. ${ }^{5}$ Early attempts to prohibit or constrain the use of armed force through multilateral treaties, such as the Covenant of the League of Nations ${ }^{6}$ and the Kellogg-Briand Pact, ${ }^{7}$ proved ineffective and were ultimately superseded by the United Nations Charter.

The UN Charter imposes specific limits on the use of force by states, apparently on the assumption that the Security Council will take responsibility for maintaining international peace and security. ${ }^{8}$ Article 2(4) of the UN Charter lays down a broad prohibition on the use or threat of force:

All Members shall refrain in their international relations from the threat or use of force against the territorial sovereignty or political independence of any state, or in any other manner inconsistent with the Purposes of the United Nations. ${ }^{9}$

Article 51 then recognizes a limited exception to this general prohibition on the use of force:

Nothing in the present Charter shall impair the inherent right of individual or collective self-defense if an armed attack occurs against a Member of the United Nations, until the Security

\footnotetext{
5 See, e.g., Christine Gray, International LaW and the Use of Force 105 (2000).

6 League of Nations Covenant art. 12 ("The Members of the League agree that, if there should arise between them any dispute likely to lead to a rupture they will submit the matter either to arbitration or judicial settlement or to enquiry by the Council, and they agree in no case to resort to war until three months after the award by the arbitrators or the judicial decision, or the report by the Council. In any case under this Article the award of the arbitrators or the judicial decision shall be made within a reasonable time, and the report of the Council shall be made within six months after the submission of the dispute.").

7 See Kellogg-Briand Pact art. 1, Aug. 27, 1928, 46 Stat. 2343, 94 L.N.T.S. 57 ("The High Contracting Parties solemnly declare in the names of their respective peoples that they condemn recourse to war for the solution of international controversies, and renounce it, as an instrument of national policy in their relations with one another.").

8 See, e.g., UN Charter art. 39 ("The Security Council shall determine the existence of any threat to the peace, breach of the peace, or act of aggression and shall make recommendations, or decide what measures shall be taken . . to maintain or restore international peace and security.").

${ }^{9}$ Id. art. 2, para. 4.
} 
Council has taken the measures necessary to maintain

international peace and security. ${ }^{10}$

The effect of these Charter provisions is to impose a number of strict limitations not only on the aggressive use of force but also on the defensive use of force. As explained below, according to the International Court of Justice (ICJ), states apparently may not use defensive force against unlawful armed aggression that is limited in its scale and effects (Part II.A) or against non-state actors using another state as a base of operations for unlawful aggression (Part II.B). As we will discuss in Part IV, alternative interpretations of current law are possible, and should be adopted.

Other limitations on responses to unlawful aggression, however, cannot be avoided through reinterpretation. ${ }^{11}$ Specifically, the text of the UN Charter seems to preclude the use of defensive force against armed attacks that have not yet occurred but that are imminent or that are not imminent but are firmly intended (Part II.C). The discussion below suggests that these limitations on the use of defensive force conflict with basic principles of justice as revealed in and adopted by domestic criminal law.

It should be noted at the outset that some scholars argue that the text of the UN Charter and the judgments of the ICJ no longer reflect the international legal rules governing the use of force; these rules are instead to be distilled from the behavior of states and the decisions of the UN's political organs. If these scholars are correct, then the situation is even worse than we suppose. We argue that international law rules are flawed and should be reformed. But if the text of the Charter is not (or no longer) law, and if the ICJ has no authority to say what the law is, then the very project of submitting international affairs to legal rules and institutions begins to break down.

For example, Thomas Franck famously argued that the Security Council tacitly amends Article 51 through its responses to apparent violations, condemning some while turning a blind eye to others. ${ }^{12}$ Franck then attempted to

\footnotetext{
${ }^{10} \mathrm{Id}$. art. 51 . Note that Article 51 does not displace the two customary constraints on the amount and kind of force that may be used, namely necessity and proportionality, but rather alters the triggering conditions under which any use of force will be legally authorized.

${ }^{11}$ Moreover, the uncertainty surrounding these limitations is itself a source of instability and injustice.

12 See, e.g., Thomas FrancK, Recourse to Force 51-52 (2002).
} 
project morally intelligible standards onto the politically-motivated decisions of the Security Council, as if it was a common law court rather than a device to stabilize the post-World War II balance of power. However, despite our misgivings about the drafting of Article 51, the fact remains that the text of the UN Charter has been signed and ratified by 192 countries. ${ }^{13}$ How many countries have ratified the unwritten amendments Franck claims to have identified, or accepted his supposition that the Security Council has the authority to change the meaning of core provisions of the Charter tacitly, at will, and on a case-by-case and ex post facto basis? None, we submit, that seek an international legal system composed of clear and stable rules of general and prospective application.

Similarly, the ICJ is the primary judicial organ of the United Nations, created by the UN Charter itself, and staffed by leading jurists from a variety of nations. Although the ICJ's decisions are binding only on the parties before the Court, those decisions must be rendered "in accordance with international law," 14 and are in fact cited as expressions of international law by other international tribunals. ${ }^{15}$ Again, despite our objections to specific ICJ decisions, the fact remains that the ICJ is the most authoritative expositor of public international law in the international system. It would be a serious mistake to treat ICJ judgments as if they carry no more weight than law review articles. If substantive reform of international law is achieved, we would want the ICJ to provide nations with guidance on its interpretation and implementation. As we shall see, the ICJ decisions that we criticize below have a plausible basis in the text of the UN Charter. It follows that if we provide the ICJ with better substantive rules there is good reason to expect that it will do a fair job interpreting and applying those rules. Finally, even if the flawed existing rules remain unreformed, it may in some cases be preferable for nations to obey the flawed rules (for example regarding non-imminent threats or reprisals) than to make up their own rules. After all, our goal is systematic legal reform, not anarchy.

\footnotetext{
13 See Growth in United Nations membership, 1945-present, UNITED NATIONS, available at http://www.un.org/en/members/growth.shtml (last visited Oct. 29, 2011).

14 Statute of the International Court of Justice art. 38, I 1, June 26, 1945, 59 Stat. 1055, 33 U.N.T.S. 993.

15 See, e.g., Prosecutor v. Kupreskic, Case No. IT-95-16-T, Trial Judgment, ๆ 524, 534 (Int'l Crim. Trib. for the Former Yugoslavia Jan. 14, 2000) (citing multiple ICJ decisions).
} 


\section{A. Barring Force Necessary to Defend Against Illegal Conduct Short of an "Armed Attack"}

As noted above, the UN Charter permits the use or threat of force only in self-defense against an "armed attack." The ICJ famously held that it is "necessary to distinguish the most grave forms of the use of force (those constituting an armed attack) from other less grave forms." 16 Force may be used only to defend against the former. ${ }^{17}$ We argue that such a rule results in injustice and uncertainty for victim states.

Criminal law does have a seriousness-of-threat limitation of sorts: one cannot use deadly force in self-defense unless threatened with death or serious bodily injury. This reflects criminal law's general proportionality requirement. But criminal law allows the use of some force to defend against any unlawful attackeven non-deadly attacks. ${ }^{18}$ The bully in the bar who knocks you down and hits your legs with his pool cue, but does not use deadly force, can be resisted with whatever force is necessary to stop the attack, short of deadly force. Imagine, however, that criminal law forbade the use of any defensive force except to repel deadly force. Such a rule would seem both unfair and unwise, since the victim of the barroom bully would be required to suffer the beating (assuming escape is impossible) while the bully would see little to deter his unlawful attack, knowing that his victim's use of even proportionate force in self-defense would be illegal. Yet the ICJ's interpretation of the UN Charter imposes just such a rule on states, barring the use of defensive force of any kind or degree against illegal aggression that does not rise to the level of an "armed attack."

This discrepancy between criminal and international law is particularly difficult to justify given that individual victims of non-lethal attacks generally have recourse to the police and the courts, while state victims of low-level armed force

${ }^{16}$ Military and Paramilitary Activities in and Against Nicaragua (Nicar. v. U.S.), 1986 I.C.J. 14, 101 (June 27) [hereinafter Nicaragua]. See also id. at 104 (stating that the I.G.J. "does not believe that the concept of "armed attack' 'includes ... assistance to rebels in the form of the provision of weapons or logistical or other support" even though "[s]uch assistance may be regarded as a threat or use of force, or amount to intervention in the internal or external affairs of other States").

17 A number of scholars have noted this gap in coverage. See, e.g., YORAM DinsteIn, WAR, AGGRESSION \& SELF-DEFENSE 193 (4th ed., 2005) ("Even leaving aside mere threats of force ..., it is clear that one State may employ some illegal force against another without unleashing a fullfledged armed attack.").

18 See, e.g., American Law Institute, Model Penal Code and Commentaries $§ 3.04$ (1985)

[hereinafter MOdEL PENAL CODE]. 
are often unable to secure an adequate response from international institutions. As we shall see in Part $\mathrm{V}$, the absence of an effective enforcement mechanism at the international level will sometimes justify recognizing a broader right of self-defense for states than for individuals. But the absence of such a mechanism weighs heavily against narrowing the right of national self-defense relative to the right of individual self-defense by imposing an "armed attack" threshold.

The ICJ's restrictive interpretation of the UN Charter's "armed attack" threshold was foreshadowed by the ICJ's first use of force decision. On October 22, 1946, two British destroyers struck sea-mines that Albania had illegally placed or knowingly allowed to be placed in its territorial waters in the Strait of Corfu, resulting in the deaths of forty-four sailors, the injury of another forty-two sailors, and damage to the ships. The U.K. sought permission to remove the mines but Albania refused. To avoid further casualties from Albania's illegal mines, British ships removed the mines without Albania's permission on November 12th and 13th. ${ }^{19}$ Even though the ICJ confirmed that Albania's refusal to remove the mines violated international law, the Court nonetheless held the U.K.'s minesweeping operation illegal. ${ }^{20}$ The ICJ rejected the U.K.'s claim that its use of force was an appropriate exercise of "self-protection or self-help." 21 The U.K.'s infringement of Albanian sovereignty was held illegal even though it was necessary to eliminate an ongoing illegal danger and was strictly limited to achieving that goal.

Imagine the criminal law corollary. A property owner places a bear trap on an easement across his property adjacent to a remote state park and rejects demands to remove it even after people are killed by it. Would we say it was unlawful for a hiker who had a right to use the trail to move the trap from the public way? Clearly not. ${ }^{22}$ Similarly, the international law rule preventing states from removing illegally placed sea mines promotes neither justice nor security, especially given the absence of any centralized authority that can be called upon to remove the danger. What seems more likely is that states will feel obliged to ignore a legal regime that is both unjust and inadequate and to protect their vital interests. Rules that compel reasonable states to violate the law hardly encourage respect for and deference to the law.

\footnotetext{
${ }^{19}$ Corfu Channel (U.K. v. Alb.), 1949 ICJ 4, 22 (Apr. 9).

$20 \mathrm{Id}$. at 35.

${ }^{21} \mathrm{Id}$.

22 See, e.g., Model Penal Code, supra note 18, § 3.02.
} 
The ICJ's overly restrictive triggering condition for defensive forcerequiring an "armed attack" - creates serious problems in other situations as well. For example, according to leading commentators, even " $[\mathrm{k}]$ idnapping nationals is not an armed attack." 23 Thus, according to the ICJ's reasoning, the UN Charter would seem to have been violated by the use of force in Operation Entebbe. On July 3-4, 1976, approximately 100 members of the Israeli Defense Forces (IDF) entered Entebbe Airport in Uganda to free 80 Israeli nationals and 25 French Jews held hostage by German and Palestinian hijackers of Air France Flight 139 and their Ugandan supporters. Forty-five Ugandan soldiers, seven hijackers, three hostages, and one IDF officer were killed in the raid. ${ }^{24}$ France strongly defended the raid as having "the purpose and the effect of freeing certain Israeli citizens who, together with French citizens, were being subject to the most detestable blackmail [and] . . . threatened with immediate death." ${ }^{25}$ The United States, United Kingdom, and Sweden also supported the raid, arguing that it involved only a limited infringement of Uganda's territorial integrity, did not undermine the general prohibition on the use of force, and was limited and proportionate to the purpose of protecting Israeli nationals. But the Soviet Union, China, and a majority of the non-permanent members of the Security Council concluded that the raid was an illegal use of force because Israel was not directly attacked. ${ }^{26}$ Indeed, according to the ICJ's reasoning, it seems that the hijacking of a plane and the kidnapping of over 100 people did not constitute an armed attack triggering Israel's legal right of self-defense, and therefore the rescue mission constituted an illegal use of force ${ }^{27}$ Criminal law principles would hold the raid to be a well-justified use of force. It is a weakness of international law that it does not clearly support the same conclusion.

Similarly, the "armed attack" threshold for the use of defensive force creates serious uncertainty regarding when states may use force in response to the use of illegal force on their territory. In its Nicaragua decision, for example, the ICJ wrote in dicta that "the sending by a State of armed bands to the territory of another State" or a similar incursion "carried out by regular armed forces" will not constitute an armed attack unless its "scale and effects" distinguish it from "a mere frontier incident." 28 In the same vein, the Ethiopia-Eritrea Claims

\footnotetext{
23 Mary Ellen O'Connell, International Law and the Use of Force, Cases and

MATERIALS 295 (2d ed., 2008).

${ }^{24}$ FRANCK, supra note 12, 82-86.

25 S.C.O.R. (XXXI), $1942^{\text {nd }}$ Meeting, 13 July 1976, at 7, 43.

26 See GRAY, supra note 5, at 31-32.

27 Thanks to Morgan Cohen for helping us sharpen this point.

28 Nicaragua, supra note 16, \195.
} 
Commission held that "[1] ocalized border encounters between small infantry units, even those involving the loss of life, do not constitute an armed attack for purposes of the Charter." 29 Neither court has made a serious effort to explain how a victim state is to tell whether the scale and effects of the use of force against its territory render it an armed attack (to which it can respond with proportionate force) or a "mere frontier incident" (to which it cannot respond with proportionate force). Such legal uncertainty not only compounds the structural disadvantages to victim states under international law, but also inhibits deterrence of unlawful aggression at the margins.

One can imagine the argument in support of such restrictive authorization of defensive force: the reciprocal use of force, even at a low level, can precipitate a broader armed conflict. Criminal law, however, has developed a legal framework that prevents escalation without depriving victims of the right to self-defense, a framework that international law could easily adopt. Under the Model Penal Code, for example, the victim of non-deadly force may use non-deadly force in self-defense, and the aggressor has no right to resist the victim in turn. If the victim escalates the conflict by responding with deadly force or force unnecessary for self-defense, however, then the initial aggressor may use necessary and proportionate force in self-defense. The initial aggressor would remain liable for the initial use of non-deadly force, while the victim would be liable for the disproportionate use of deadly force.$^{30}$ At no time, however, is the victim deprived of the right to use proportionate and necessary force in self-defense.

Similarly, the best way to avoid escalation of international conflicts is for international law to censure the aggressing state's initial use of force and permit the defending state to use necessary and proportionate force in response. ${ }^{31}$ The

\footnotetext{
${ }^{29}$ Eritrea/Ethiopia, Partial Award, Jus Ad Bellum Ethiopia's Claims 1-8, 19 December 2005, ๆ 11 available at http://www.pca-cpa.org, 2006 ILM 430. See also id. ๆ 12 (finding "geographically limited clashes between small Eritrean and Ethiopian patrols along a remote, unmarked, and disputed border. The Commission is satisfied that these relatively minor incidents were not of a magnitude to constitute an armed attack by either State against the other within the meaning of Article 51 of the UN Charter.").

30 See Model Penal Code, supra note 18, Comment to $\S 3.04$ at 49-51.

31 See Christopher Greenwood, The International Court of Justice and the Use of Force, in FIFTY YEARS OF THE INTERnATIONAL COURT OF Justice 379 (Vaughan Lowe \& Malgosia Fitzmaurice eds., 1996) ("Of course, one can sympathize with the Court's evident desire to ensure that a minor use of force does not lead to a wholly excessive response. Any exercise of the right of self-defence is, however, subject to the principle of proportionality. Insistence on compliance with that principle is a more effective and realistic way of seeking to prevent an excessive military response than the creation of an artificial distinction between different degrees of the use of force.").
} 
aggressor state should have no right to defend itself against proportionate and necessary defensive force, but if the defending state escalates the conflict through a disproportionate or unnecessary response, then it should be liable for doing so and the aggressing state may use necessary and proportionate force to defend itself. ${ }^{32}$ Importantly, this approach to regulating escalation should apply both above and below the "armed attack" threshold.

It is true that uses of force short of armed attacks can often be dealt with through non-forceful reprisals or diplomatic responses. In such cases, the use of defensive force is indeed illegitimate - but only because the use of unnecessary force is always illegitimate, not because of any qualitative difference between limited unlawful aggression and armed attacks. Just as domestic criminal law permits self-defense against illegal uses of force that do not reach the level of "deadly force," so too should international law permit forceful defense against illegal force that does not reach the level of an "armed attack."

\section{B. Potentially Barring Force Against Armed Groups Operating from the Territory of Another State}

One of the most surprising aspects of the international law governing the use of defensive force is that it remains unclear whether states may use defensive force against armed groups using another state as a base of operations. This lack of clarity is particularly surprising because the underlying security problem is neither new nor obscure. On December 29, 1838, British and Canadian Royalist forces entered U.S. waters to destroy the steamboat SS Caroline, which had been used by American sympathizers to supply money, provisions, and arms to a group of Canadian rebels that had staged attacks against the colonial government in Canada. The Caroline incident is universally viewed as the locus classicus of the

\footnotetext{
32 We appreciate that proportionality is not a clear rule but rather a somewhat vague standard, and that more precise legal guidance would be desirable. However, the distinction between armed attacks and mere uses of force is no more clear than the distinction between proportionate and disproportionate uses of force. Indeed, if international law expects states to be able to distinguish between mere uses of force and armed attacks for the purpose of determining whether the use of defensive force is permissible, then it should similarly expect states to be able to draw the same distinction for the purpose of determining whether a mere use of force or an armed attack would be a proportionate response. If proportionality is sufficiently clear to guide state behavior above the "armed attack" threshold, then it should be clear enough to guide state behavior below that threshold as well. It makes little sense to rely on a legal standard when the stakes are relatively high but not when the stakes are relatively low.
} 
customary international law of self-defense, yet the legal status of the case itself under the UN Charter seems uncertain at best.

The ICJ has only recognized two forms of armed attacks as triggering a right to use defensive force, namely "action by regular armed forces across an international border" and "the sending by or on behalf of a State of armed bands, groups, irregulars or mercenaries, which carry out acts of armed force against another State . . 'or its substantial involvement therein." 33 Leading scholars have concluded that "where a state is not responsible for terrorist attacks, Article 51 may not be invoked to justify measures in self-defense" taken on the territory of the host state. ${ }^{34}$ The ICJ has suggested as much in a 2004 decision, ${ }^{35}$ and has so far declined to clarify its position on this issue. ${ }^{36}$ As we will argue in Part IV, there are sound arguments to be made in support of an interpretation of international law that permits the use of defensive force against armed groups operating from the territory of another state, but at present the law is surprisingly and disappointingly unsettled.

The legality of using force against armed groups on the territory of another state is of pressing concern to the United States. In 2004, the Bush Administration began launching frequent missile strikes against $\mathrm{Al}$ Qaeda and Taliban targets in areas of Pakistan. ${ }^{37}$ The frequency of these missile strikes has apparently increased under the Obama Administration, ${ }^{38}$ but their legality

${ }^{33}$ Nicaragua, supra note 16, at 103 195, (quoting Definition of Aggression, G.A. Res. 3314 (XXIX), 29th Sess., Art. 3, para. G (Dec. 14, 1974)).

${ }^{34}$ O'ConNell, supra note 23, at 320. See also id. at 319 ("If the state or states where the terrorist group is found happens to be making a good faith effort to stop the terrorist group and has some basic ability to do so, then the victim state cannot hold the territorial state responsible for the acts of terrorism and may not respond with armed force on the territory of that state."). See also Oscar Schachter, The Laweful Use of Force by a State Against Terrorists in Another Country, 19 ISR Y.B. H.R. 209, 216 (1989).

${ }^{35}$ Legal Consequences of the Construction of a Wall in the Occupied Palestinian Territory, Advisory Opinion, July 9, 2004, 43 I.L.M. 1009, 139 (rejecting Israel's claim of self-defense partly on the ground that Israel did not allege that the terrorist attacks the disputed wall was intended to prevent were attributable to any state).

36 See, e.g., Armed Activities on the Territory of the Congo (Dem. Rep. Congo v. Uganda), 2005 ICJ 223, \ 147 (concluding that "the Court has no need to respond to the contentions of the Parties as to whether and under what conditions contemporary international law provides for a right of self-defense against large-scale armed attacks by irregular forces").

${ }^{37}$ See, e.g. David Rohde and Mohammed Khan, Ex-Fighter For Taliban Dies in Strike In Pakistan, N.Y. Times at A6 (June 19, 2004).

38 See Phil Stewart and Robert Birsel, Under Obama, Drone Attacks on the Rise in Pakistan, ReUTERS (Oct. 12, 2009), http://www.reuters.com/article/2009/10/12/idUSN11520882 ("There have 
remains in question. ${ }^{39}$ As O'Connell has argued, under the ICJ's interpretation of Article 51, it seems that "significant force may only be used on the territory of a state that is responsible for an armed attack on the defending state." ${ }^{40}$ Since "[t]he only attack on the United States that could give rise to the right of self-defense . . . occurred on 9/11" and since "Pakistan is in no respect responsible for the 9/11 attacks," O'Connell concludes that " $[\mathrm{t}]$ he United States has no basis . . . for attacking in self-defense on Pakistani territory." 41 While one may legitimately argue that the strikes kill a disproportionate number of innocent civilians and create resentment among the local civilian population, ${ }^{42}$ it remains problematic that international law appears to prohibit such strikes entirely rather than to regulate their use.

Most famously, on May 1, 2011, a team of U.S. Navy SEALs entered Pakistan, without the Pakistani government's prior knowledge or specific consent, with direct orders from President Obama to kill Al Qaeda leader Osama bin Laden. Consistent with her position on U.S. drone strikes in Pakistan, Professor O'Connell argues that the use of military-level force to kill bin Laden on Pakistani territory without the consent of the Pakistani government would violate international law. ${ }^{43}$ At the time of her writing, Professor O'Connell held out the

been 39 drone strikes in Pakistan since Obama took office not quite nine months ago, according to a Reuters tally of reports from Pakistani security officials, local government officials and residents. That compares with 33 strikes in the 12 months before Obama was sworn in on Jan. 20.”) (paragraph break omitted).

39 Compare Philip Alston, United Nations Human Rights Council, Report of the Special Rapporteur on extrajudicial, summary or arbitrary executions, Study on targeted killings, A/HRC/14/25/Add.6 (May 28, 2010), with Remarks of Harold Hongju Koh, Legal Adviser, US Dept. of State, The Obama Administration and International Law (Am Society of Intl Law 2010), available at www.state.gov/s/l/releases/remarks/139119.htm (visited Nov 20, 2010).

40 Mary Ellen O’Connell, Unlawful Killing With Combat Drones: A Case Study of Pakistan, 2004-2009, in SHOOTING TO Kill: THE LAW GOVERNING LETHAL FORCE IN CONTEXT [SSRN, revised version Dec. 20th, page 19], (Simon Bronitt ed., forthcoming 2010), available at http://ssrn.com/abstract=1501144. See also id. at 15 ("Even where militant groups remain active along a border for a considerable period of time, their armed cross-border incursions are not considered attacks under Article 51 giving rise to the right of self-defense unless the state where the group is present is responsible for their actions.").

${ }^{41} I d$.

42 See, e.g., David Kilcullen \& Andrew McDonald Exum, Death From Above, Outrage Down Below, N.Y. TiMES (Mar. 17, 2009), http://www.nytimes.com/2009/05/17/OPINION/17EXUM.HTML?PAGEWANTED=ALL. 43 Mary Ellen O'Connell, The bin Laden Aftermath: Abbottabad and International Law, FOREIGN POLICY BLOG (May 4, 2011), http://afpak.foreignpolicy.com/posts/2011/05/04/the_bin_laden_aftermath_abbottabad_and_i 
hope that the SEAL team used only police-level rather than military-level force, was ordered to capture bin Laden unless he posed a lethal threat to them, and only killed him to defend themselves. However, subsequent revelations make clear that the SEALs used military-level force including attack helicopters, explosives, and assault rifles; that the SEALs were ordered to kill bin Laden unless he affirmatively surrendered; and that bin Laden was clearly unarmed at the time he was killed. ${ }^{44}$

Some scholars criticize the blanket permission given by the law of armed conflict to kill opposing combatants, even if they can be safely captured. ${ }^{45}$ Perhaps this is another area in which international law should track criminal law more closely by permitting lethal force against an individual only when non-lethal force is insufficient to incapacitate that individual. But the point for now is that international law seems to prohibit the use of military-level force on the territory of a non-consenting state even when directed against the leader of an armed group operating from the territory of that state.

To construct a parallel situation in the domestic context, imagine that a gunman is firing on a crowd from a nearby rooftop and the criminal law of the jurisdiction prohibits those fired upon from crossing the property line in order to stop the shooter. Clearly, no society would permit such a limitation on the use of defensive force, yet international law would seem to. The fact is that imposing such a limitation is less justifiable in the international context than the domestic criminal law context. In the latter, the victim can call the police, who will rush over to use the necessary force. ${ }^{46}$ In the international context, however, there are no police to call. No one will come and put down the ongoing aggression. The victim state and its allies must either do nothing to defend themselves or must use force in violation of international law - a predicament that fails to promote justice, stability, or respect for international law.

nternational_law. O'Connell suggests that the Pakistani government waived its objection to the operation, but such a waiver presupposes the violation of Pakistani sovereignty.

44 See Nicholas Schmidle, Getting Bin Laden: What Happened that Night in Abbottabad, New Yorker, Aug. 8, 2011, http:/ / www.newyorker.com/reporting/2011/08/08/110808fa_fact_schmidle?currentPage=all.

45 See, e.g., Adil Ahmad Haque, Criminal Law and Morality at War, in PHILOSOPHICAL Foundations OF Criminal Law 481 (R.A. Duff \& Stuart P. Green eds., 2011); Gabriella Blum, The Dispensable Lives of Soldiers, 2 J. LEG. ANALYSIS 69 (2010).

46 The victim is not legally obliged to wait for the police if doing so risks greater harm. See, e.g. Model Penal Code, supra note 18, § 3.04(1), 3.04(2)(b) (1985). 
Such legal uncertainty is a serious problem for countries that are embroiled in ongoing conflicts with armed groups based in neighboring countries. For example, since 1992, a separatist group called the Kurdistan Workers Party (PKK) has repeatedly attacked Turkish government and military facilities, including bombing the Turkish embassy in Strasbourg and carrying out 15 suicide bombings inside Turkey between 1995 and 1999. The PKK has operated out of the Kurdish area of Northern Iraq since the creation of a no-fly zone following the First Gulf War resulted in a de facto Kurdish state in that area. Frequent clashes along the Iraqi border with Turkey since 2003 have left approximately 246 security personnel dead while 1,325 PKK members have been captured. The conflict as a whole has left over 37,000 people dead. Turkey has staged five major incursions into Iraq since 1992 to combat the aggression. ${ }^{47}$ Although Turkey's incursions would seem to be in technical violation of the UN Charter, Iraqi protests "did not lead to a meeting of, let alone action by, the [Security] Council or the [General] Assembly." 48 As Part III discusses at greater length, legal rules that are seen as unjust (such as the ICJ's apparent rule limiting self-defense to armed attacks by states) are regularly ignored and only undermine the law's credibility and long-term effectiveness.

\section{Barring Force Necessary to Defend Against an Attack that Has Not Yet Begun}

The text of Article 51 limits the use of defensive force to situations in which "an armed attack occurs." This permits the use of force to repel either an ongoing attack or an "incipient" attack that has begun but is still in its early stages and whose effects have not yet been felt. ${ }^{49}$ The text of the Charter does not permit states to use force before "an armed attack occurs" in order to defend against a planned attack; it also forbids the use force even against an imminent attack that has not yet begun even though preparations for the attack have been made and there is clear evidence of the intent to attack and no realistic opportunity of

\footnotetext{
47 See FRANCK, supra note 12, at 63. More recently, Turkey has received the new Iraqi government's consent to conduct cross-border operations against the PKK. See, e.g., Sebnem Arsu, Turkey Deploys Thousands in Pursuit of Kurdish Rebels, N.Y. Times, Oct. 20, 2011, at A12, available at http:/ /www.nytimes.com/2011/10/21/world/europe/turkey-deploys-thousands-of-troopsagainst-pkk.html.

${ }^{48} \mathrm{Id}$.

${ }^{49}$ For instance, if a missile is launched by one state against another state, the victim state does not have to wait until the missile strikes before using defensive force against the aggressing state. See, e.g., DinsteIn, supra note 17, at 187.
} 
achieving a negotiated solution. In other words, victim states are left to brace themselves for the oncoming assault. ${ }^{50}$

We agree that the use of defensive force is typically not legitimate absent an ongoing or incipient attack, but defensive force ought to be authorized whenever it is necessary to prevent an imminent attack. To better understand the problem, consider the Six Day War. In May 1967, Egypt expelled the United Nations Emergency Force from the Sinai Peninsula, which had been stationed there since 1957 to provide a buffer zone between Egypt and Israel after the Suez Crisis of 1956. Egypt then closed the Straits of Tiran to Israeli ships; secured unified command of the Iraqi and Jordanian armed forces; heightened aerial reconnaissance, including over Israel's nuclear research facility; and amassed 2,880 tanks and 465,000 soldiers on the Israeli border. On June 5, 1967, Israel attacked and substantially destroyed the Egyptian air force. ${ }^{51}$ Despite mounting evidence of an impending armed attack of devastating proportions, the order to attack had not been given, no borders had been crossed, and no shots had been fired. Israel's use of force, though apparently necessary, proportionate, and in response to an imminent armed attack, was not justified under the Charter's authorization to use defensive force only "if an armed attack occurs."

In some instances, states anticipated an impending attack but chose not to use force for fear of incurring legal, political, and reputational costs. For example, in the weeks prior to the 1973 Arab-Israeli War, the Israeli government received as many as eleven warnings of an impending attack, including from King Hussein of Jordan, and observed Egyptian and Syrian troop movements and training exercises consistent with preparations for a major military operation. On the morning of October 6, 1973, Prime Minister Golda Meir decided against a preemptive strike for fear of alienating critical allies, reasoning that "[i]f we strike first, we won't get help from anybody." "52 The same afternoon Egyptian air and ground forces struck Israeli positions in the Sinai, beginning a three-week long war that claimed thousands of lives and ended in a bloody stalemate. Apparently

\footnotetext{
${ }^{50}$ Id. See also FRANCK, supra note 12, at 50 (concluding that "it is beyond dispute that the negotiators deliberately closed the door on any claim of 'anticipatory self-defense,' a posture soon to become logically indefensible by the advent of a new age of nuclear warheads and long-range rocketry").

51 See Robert A. Zayac, Jr., United States'Authority to Legally Implement the Self-Defense and Anticipatory Self-Defense Doctrines to Eradicate the Threat Posed by Countries Harboring Terrorists and Producing Weapons of Mass Destruction, 29 S. ILL. U. L.J. 433, 455 (2005).

52 See Abraham Rabinovich, The Yom Kippur War 89 (2004).
} 
international law expects states to accept similar risks and bear similar losses rather than use anticipatory force.

By contrast, modern criminal law increasingly rejects even the imminentthreat requirement, shifting its focus from the timing of the threat to the timing of force needed for effective defense. Thus, the Model Penal Code drops the requirement of an "imminent threat" in favor of a requirement that the defensive force be "immediately necessary." 53 The victim may use the force needed to defend against an illegal attack before his or her window of opportunity closes, even if the threatened attack is not yet imminent. ${ }^{54}$

Criminal law scholar George Fletcher and international law scholar Jens David Ohlin have defended the imminence requirement by arguing that "[w]aiting ensures a stronger case that only the defender is acting in legitimate self-defense." 55 However, even if evidence of an imminent attack is typically stronger than evidence of a non-imminent attack, it does not follow that evidence of a non-imminent attack is never sufficient to justify anticipatory force.

If State $A$ masses troops on its border with State $B$, this can suggest that State $A$ is planning an imminent attack. If, in addition, State $B$ intercepts a communication between State $A$ 's civilian and military leaders clearly communicating its firm intention to attack State $B$ on a specific date or during a specific period in the future, then this is even stronger evidence of a non-imminent attack. For example, if Israel had learned weeks in advance that Egypt planned to strike on Yom Kippur then, if it was impossible to avoid war through other means (including by revealing the Egyptian plan), Israel would have been justified in using force before the attack was temporally imminent. To be clear, evidence of non-imminent attacks must meet an appropriate threshold of sufficiency before preventive force is justified, and states may not act on insufficient evidence simply because doing so reduces the risk to their security. However, once sufficient evidence of a non-imminent attack is in hand, states ought not be required to wait until the attack is imminent simply in order to obtain still more evidence.

\footnotetext{
${ }^{53}$ Model Penal Code, supra note 18, § 3.04 cmt. 39-40 (1985); see also PaUl H. Robinson, CRIMINAL LAW 409-12 (1997).

54 Model Penal Code, supra note 18, § 3.04(1).

55 George P. Fletcher \& Jens David Ohlin, Defending Humanity: When Force is JUSTIFIED AND WHY 169 (2008).
} 
Consider the problem facing Britain in World War II when France, then a neutral power with whom Britain was not at war, signed an armistice with Germany on June 22, 1940, which provided in part that the French fleet would fall under German or Italian supervision. The British feared that the French fleet at Mers el-Kebir, Algeria, would be used by the Germans against British ships in the Mediterranean. The French assured the British that they would not allow Germany to use French ships against Britain but the British felt such assurances could not be relied upon given the terms of the armistice just signed. The British offered the French commander at Mers el-Kebir the alternatives of joining the fight against Germany, sailing to British ports where the ships would be decommissioned, or sinking the ships themselves. The French refused these options. On July 3, British ships attacked the French fleet, destroying one battleship and damaging six others. The French commanders finally surrendered the fleet, which remained out of Nazi control for the duration of the war. ${ }^{56}$ The Allies believed that, if they had not attacked the ships, if they had waited until it was shown that the Germans were about to use the ships against them, then it would have been too late for them to put the ships out of commission. If they were to be successful, they had to act while they still had the opportunity for success.

Similarly, in December 1941, "[t]here was strong evidence of Japan's preparations to invade the Dutch East Indies." 57 Rather than wait for the attack or even for the attack to become imminent, the Netherlands declared war on Japan. Had the Dutch waited until the Japanese attack was imminent, they might have suffered their own Pearl Harbor. Both Allied actions, against the Japanese and the French fleet, seem reasonable under the circumstances, and have been generally accepted as reasonable, ${ }^{58}$ yet both appear impossible to justify under post-Charter international law. Again, forcing states to break international law in

\footnotetext{
56 See Irwin J. Kappes, Mers-el-Kebir: A Battle Between Friends, Military History Online (Mar. 15, 2003), http://www.militaryhistoryonline.com/wwii/articles/merselkebir.aspx.

57 George K. Walker, Anticipatory Collective Self-Defense in the Charter Era: What the Treaties Have Said, 31 CORNELL INT'L L.J. 321, 358 (1998).

58 See United States v. Araki, Judgment of the International Military Tribunal for the Far East (Nov. 4-12, 1948), reprinted in 1 The TOKYOJUdgment: THE INTERNATIONAL MiLitARy TRIBUNAL FOR THE FAR EAST (I.M.T.F.E.) 29 APRIL 1946-12 NOVEMBER 1948382 (B.V.A. Röling \& C.F. Rüter eds., 1977) ("The fact that the Netherlands, . . . fully apprised of the imminence of the attack [by Japan], in self-defense declared war against Japan on 8th December and thus officially recognised the existence of a state of war which had been begun by Japan, cannot change that war from a war of aggression [by] Japan into something other than that.").
} 
order to protect themselves or their allies is not only an ultimately hopeless exercise but also not likely to promote justice, stability, or respect for the law.

\section{Should International Law Care Whether It Is Seen as Unjust?}

Part II illustrates the injustice of international law's limitations on the use of defensive force. In a variety of important contexts, victim states are asked to simply suffer unlawful aggression and forego necessary and proportionate defensive force, presumably because the drafters of the UN Charter thought the Security Council would be a more effective guarantor of world order than it has proven to be over the last sixty years. Part V examines whether such rules are defensible in a world where no law enforcement power exists to provide the protection that victim nations are barred from providing for themselves. But even if one were to ignore the consequences of these rules for peace and stability, one may oppose international law's limitations on the use of force simply because they are unjust. The current rules too often force victim states to either suffer an attack or to break the law themselves by using necessary and proportionate defensive force.

The apparent injustice of international law rules governing the use of defensive force is not merely objectionable on its own terms but also undermines the stability and efficacy of international law over the long term. Importantly, social scientists have taught us something in the past several decades about the power of normative forces in controlling conduct and in the dependency of institutional effectiveness on the moral reputations they earn. Promoting unjust rules, as Part II shows that current international law regularly does, undermines the moral credibility of the law, which in turn undermines its ability to earn deference and compliance from those it seeks to govern. Reputation is particularly important for international law, where the absence of an effective enforcement authority leaves the law heavily dependent upon states' willingness to follow its rules because they are perceived as just and fair. In the end, international law's reliance upon unjust rules subverts its capacity to control the use of force by states.

\section{A. The Power of Normative Influence}

Consider that, even where there is no coercive law enforcement authority at hand, people commonly remain law-abiding. This phenomenon demonstrates the power of normative influence, arising from the norms shared by a person's community and from the norms internalized by the individual. Social science has come to appreciate the enormous power of normative influence. Indeed, there is 
good evidence to suggest that even in the context of domestic criminal justice, where the existence of a functioning criminal justice system offers a significant deterrent threat, the power of normative influence is greater than that of general deterrence..$^{59}$

Importantly, international law scholars have persuasively argued that perceptions of legitimacy and fairness influence the behavior of states much as these perceptions influence the behavior of individuals. ${ }^{60}$ In the international context, where no centralized law enforcement authority exists, the powerful forces of normative influence may be among the most effective means available for gaining compliance. ${ }^{61}$

Can international law harness the forces of normative influence? There is good reason to believe that it can, but only if it formulates its rules in a way that earns it a reputation as a moral authority. If international law rules governing the use of force track shared intuitions of fairness and justice, then violators of those rules will be seen as doing something morally condemnable, and would be stigmatized as a result. By contrast, if international law rules regularly conflict with shared intuitions of justice, then the rules' moral authority will be undermined. If international law earns a reputation for regularly "getting it wrong," then the violation of its rules is not likely to trigger moral condemnation or stigma, but is more likely to trigger resistance and subversion. Each time a state violates international law's unjust defensive force rules, yet is seen as engaging in conduct accepted as necessary and proper, international law's reputation is incrementally undermined, and the condemnation for violating international law's force rules is incrementally weakened. Undermining international law's condemnatory effect is

59 See, e.g., Tom Tyler, Why People Obey the LaW 59 (1990) (finding a strong positive correlation between perceptions of legitimacy and compliance with criminal law); see also Paul $\mathrm{H}$. Robinson, Geoff Goodwin \& Michael Reisig, The Disutility of Injustice (2010) (submitted for publication) (empirical study showing crime-control costs from perceived injustices of criminal law).

60 See, e.g., THOMAS M. Franck, FAIRnESS In INTERNATIONAL LAW AND INSTITUTIONS (1995); Thomas M. Franck, The Power of Legitimacy Among Nations (1990).

61 Of course, normative influence cannot guarantee norm-compliance, particularly on the part of states that reject the values of the international community. As Part V.C explains, expanding the right of victim states to use defensive force can provide an important deterrent to aggressor states that are impervious or resistant to normative influence. Conversely, some states may conform to rules they view as unjust because they believe it is in their overall interest to do so. Indeed, since the UN Charter is so difficult to modify, many states may conform to its rules thinking that reform is impossible and that unjust rules are better than none at all. We believe, however, that reform is possible and, if possible, imperative. 
a serious problem when the law seeks to condemn the states that really do deserve condemnation. When the moral credibility of international law is compromised, so too is its ability to harness the forces of social influence.

Similarly, and relatedly, if international rules fail to earn a reputation for moral credibility, a state is more likely to feel justified in taking matters into its own hands in violation of those rules - what in the private context would be vigilantism. In the international context, with no centralized law enforcement authority to exercise force to maintain order, this is a particular problem. Without a central enforcement authority and with an international system dependent upon normative rather than coercive enforcement power, international law rules with little moral force encourage individual states to do as they choose.

An earned reputation for moral authority also could help gain compliance from states in situations in which the appropriate rule of conduct is unclear, a special problem in international law where there remain so many areas of complexity and indeterminacy. If international law has earned moral credibility, states are more likely to defer to it in borderline or ambiguous situations. Where international law has proven itself insensitive to notions of fairness and justice, its rules are less likely to earn such deference.

Finally, international law rules that have earned a reputation as reliable moral authorities can affect the development of new international norms. Again, this is particularly important in international law, where many issues remain to be resolved. ${ }^{62}$ When international law formally prohibits certain conduct, for example, its credibility reinforces the conclusions that such conduct is indeed condemnable. On the other hand, an international law that is perceived as out of touch with principles of justice and fairness is less likely to have much normshaping effect when it prohibits conduct. ${ }^{63}$ Unjust rules can be discounted as further evidence of international law's insensitivity to doing justice, and render

\footnotetext{
62 The debate over the legality of land mines provides but one example of an emerging international law norm whose moral legitimacy remains disputed. See Review of Land Mine Treaty 'to Take Some Time,'State Dept. Says, N.Y. Times, Nov. 26, 2009, at A10; Convention on the Prohibition of the Use, Stockpiling, Production and Transfer of Anti-Personnel Mines and on their Destruction, Sept. 18, 1997, 2056 U.N.T.S. 211, available at http://www.icbl.org/treaty/text (providing the text of the mine ban treaty).

${ }^{63}$ Cf. Paul H. Robinson, Distributive Principles of Griminal law: Who Should Be Punished How MuCH? 175-201 (2008); Paul H. Robinson \& John Darley, The Utility of Desert, 91 Nw. UnIV. L. REV. 453, 471-74 (1997); Paul H. Robinson \& John M. Darley, Intuitions of fustice: Implications for Criminal Law and Fustice Policy, 81 S. CAL. L. REV. 1, 28-29 (2007).
} 
international law increasingly irrelevant to the public conversation regarding whether the conduct at hand is indeed condemnable.

\section{B. Shared Intuitions of Justice on the Use of Defensive Force}

How can international law build its moral credibility with the international community? A necessary part of that process is to have rules that avoid conflict with people's shared intuitions of justice. Although it has not always been fully appreciated, it seems clear now that human beings share intuitions about many aspects of just conduct, including what constitutes the justified use of force. Many of these core beliefs are shared across all demographics. ${ }^{64}$

Empirical studies reveal lay intuitions of justice on a wide variety of issues relating to the use of defensive force. Lay persons support the use of force necessary to defend against unjustified aggression, even the use of deadly force. ${ }^{65}$ (Indeed, lay intuitions tend to go much further than even domestic criminal law in authorizing the use of defensive force. ${ }^{66}$ ) The same overwhelming support for victims is seen in tests of lay judgments about the use of force in defense of property. Lay people refuse to impose liability where a victim uses force necessary to defend property, ${ }^{67}$ as one would expect, but also take a similar view even where the necessity for the use of force is questionable, ${ }^{68}$ where there is no imminent threat so the defender perceives no immediate need for force, ${ }^{69}$ and where the

\footnotetext{
64 See, e.g., Paul H. Robinson \& Robert Kurzban, Concordance and Conflict in Intuitions of fustice, 91 Minn. L. REV. 1829, 1833 (2007).

65 Paul H. Robinson \& John M. Darley, Justice, Liability \& Blame: Community Views AND THE CRIMINAL LAW 56 table 3.1, row 2 (1995) [hereinafter JLB].

${ }^{66}$ For example, lay intuitions would justify use of force even if the defender knows that a killing in self-defense is unnecessary because he could have safely retreated from his home. $I d$. at table 3.1, row 5 . So sympathetic are lay persons to the target of aggression that they commonly also impose no liability even if the defender uses more force than is necessary because he is mistaken about the threat. $I d$. at table 3.1, row 6 . Reflecting this same degree of sympathy and support, lay persons may provide liability but little or no punishment even if the defender knew that the killing was not necessary because he could have safely retreated in a public place (the subjects on average reduce liability from 15 years in the case of the same killing without self-defense to 9.6 months for killing where it could have been avoided by retreating in a public place). Id. at table 3.1, row 4 .

Additionally, lay persons commonly provide no liability where the defender killed in a mistaken belief that no retreat was possible. Id. at table 3.1, row 7. Even where the defendant kills an unarmed attacker knowing deadly force is not necessary, the defender's liability is only 5.8 years, rather than the 15 years imposed for the same killing not in self-defense. $I d$. at table 3.1, row 3 .

${ }^{67} \mathrm{Id}$. at 56-57 table 3.6, row 1 .

${ }^{68} \mathrm{Id}$. at table 3.6, row 2.

${ }^{69} \mathrm{Id}$. at table 3.6, row 4 .
} 
defender chooses to use more force than is necessary. ${ }^{70}$ Indeed, even where the victim uses deadly force, whether he knows that it is not lawful or mistakenly believes that it is lawful, lay persons as a group impose essentially trivial liability. ${ }^{71}$ This treatment of force in protection of mere property, especially the views on the use of deadly force in such cases, suggests perhaps only modest support for the limitations of necessity and proportionality.

The same overwhelming sympathy and support for victims and intended victims of aggression reveals itself not only in lay people's support for defensive force but also in their view on aggressive force used for law enforcement purposes after an offense is complete. Lay persons typically impose no liability on citizens who use nondeadly force to capture an offender fleeing from a rape or from a property destruction offense. ${ }^{72}$ Perhaps even more striking, they typically impose no liability even for the use of deadly force for such capture after a rape, ${ }^{73}$ and impose only trivial liability for the use of deadly force for capture after the property offense. ${ }^{74}$ Indeed, so sympathetic are they that even when the victim uses aggressive force to capture but is mistaken as to the identity of the original attacker, and uses force against the wrong person, lay people still refuse to impose liability for the use of nondeadly force, ${ }^{75}$ and impose only trivial liability for the use of deadly force. ${ }^{76}$ It is fair to conclude that lay support for the use of force against aggressors and law-breakers extends to both defensive and aggressive action. ${ }^{77}$

Importantly, the intuitions of justice reflected in these studies are not unique to Americans. While there is little cross-cultural work on defensive force rules in particular, there are many studies showing that many intuitions of justice are shared across societies. First, according to empirical studies, "the intuition that

${ }^{70} \mathrm{Id}$. at table 3.6 , row 5 .

${ }^{71} \mathrm{Id}$. at table 3.6, rows 6, 7 (subjects imposed liability on average of 2.6 weeks).

${ }^{72} \mathrm{Id}$. at 74 table 3.7 , rows 3,7 .

${ }^{73} \mathrm{Id}$. at table 3.7, row 1 .

${ }^{74} \mathrm{Id}$. at table 3.7 , row 5 (subjects imposed liability on average of 2.6 weeks).

$75 \mathrm{Id}$. at table 3.7 , rows 4,8 .

${ }^{76} \mathrm{Id}$. at table 3.7 , rows 2, 6 (subjects impose liability on average of 5 days for the deadly force against the wrong person after the rape, and 3.2 months for the deadly force against the wrong person after the property offense).

77 The same sort of lay sympathy and support has been shown for aggressive conduct designed to avoid a greater harm (lesser evils situations) - as in the burning of another's property to serve as a firebreak to protect a town - even where it turns out that the actor is mistaken as to the need for his conduct. See Paul H. Robinson \& John M. Darley, Testing Competing Theories of Justification, 76 N.C. L. REV. 1095, 1124 table 3, rows 6 (justified burning), 9-11 (mistaken) (1998). 
those who commit wrongs should be punished seems to be universal."78 Philosopher Ray Jackendoff adds that "[i]n our culture, the legal system punishes not only physical aggression like assault, but also economic aggression like stealing. Similar institutions are found in some form in every culture, even in the absence of written legal codes." Developmental psychologist Jerome Kagan concurs, including the intuition that serious wrongdoing should be punished as one of "a limited number of universal moral categories that transcend time and locality."79 Indeed, this conclusion is consistent across a number of studies ${ }^{80}$ and is consistent with the finding that " $[\mathrm{h}] \mathrm{arm}$, broadly construed to include psychological harm, injustice, and violation of rights, may be important in the morality of all cultures." 81

Moreover, people "everywhere [also] share intuitions of justice about the relative blameworthiness of serious wrongdoing." 82 Within different cultures survey data obtained by asking respondents to rank various instances of wrongdoing indicate that there is consensus as to the relative amounts of punishment those instances deserve. For instance, Graeme Newman, surveying subjects from supposedly drastically different cultures, finds, "If one were to order the [instances of wrongdoing] according to the proportions of each country sample criminalizing them, one would find a general consensus across all countries as to the extent that all acts should be tolerated." 83 Looking broadly at his respondents' answers, Newman reports that there is "general agreement in ranks across all countries." 44 Later studies - typically building on the work of Thorsten Sellin and Marvin Wolfgang's study of American rankings of crime

78 Robinson \& Kurzban, Concordance, supra note 64, at 1852.

${ }^{79}$ Jerome Kagan, The Nature of The Child 118-19 (1984).

80 See Robinson \& Kurzban, Concordance, supra note 64, at 1852-53 (collecting studies).

${ }^{81}$ Jonathan Haidt et al., Affect, Culture, and Morality, or Is It Wrong to Eat Your Dog.? 65 J. Personality \& Soc. Psychol. 613, 613 (1993).

${ }^{82} \mathrm{Id}$. at 1862 . The reason that intuitions as to punishment are so consistent may be that they are derived from evolutionary processes. See Paul H. Robinson, Robert Kurzban \& Owen D. Jones, The Origins of Shared Intuitions of Justice, 60 VAND. L. REV. 1633, 1646-54 (2007).

${ }^{83}$ Graeme Newman, Comparative Deviance: Perception and LaW IN SiX Gultures 115 (1976).

${ }^{84} \mathrm{Id}$. at 141 . 
seriousness ${ }^{85}$ - have found consensus between Americans and Taiwanese, ${ }^{86}$ Americans and Kuwaitis, ${ }^{87}$ and Palestinian Arabs and Israeli Jews. ${ }^{88}$

That intuitions of justice concerning defensive force in particular are shared across cultures is also reflected in the fact that the basic American limitations on the use of defensive force - requiring an unlawful threat and a necessary and proportionate response - are shared by many other countries, even those from quite different legal traditions. Kremnitzer and Ghanayim find that "a 'universal view' of the proportionality requirement is shared in English, American, Canadian, French, Swiss, Spanish, Austrian, Norwegian and Finnish law." 89 Similarly, Islamic law provides an analogous right of self-defense: "There is a natural right to self-defense. One may defend oneself from a criminal act that poses an imminent threat to person or property, but only necessary force may be used. An intruder who might be repelled with a stick may not be shot and killed; neither may one pursue an intruder who has retreated and is no longer a threat. Violation of the limits of self-defense is aggression and renders one criminally liable." 90 Indeed, according to the Human Rights Council: "International bodies and States universally define self-defence in terms of necessity and proportionality." 91

85 See Thorsten Sellin \& Marvin E. Wolfgang, The Measurement of

DELINQUENCY 263-65 (1967) (reporting similar rankings in different socioeconomic groups).

86 See Marlene Hsu, Cultural and Sexual Differences on the Fudgment of Criminal Offenses: A Replication Study of the Measurement of Delinquency, 64 J. CRIM. L. \& CRIMINOLOGY 348, 350 (1973).

87 See Sandra S. Evans \& Joseph E. Scott, The Seriousness of Crime Cross-Culturally, 22 CRIMINOLOGY 39, 53 (1984) ("The seriousness of violent, property, and white collar offenses were . . perceived similarly by the United States and Kuwaiti students.").

88 See Sergio Herzog, Public Perceptions of Crime Seriousness: A Comparison of Social Divisions in Israel, 39 ISR. L. REV. 57, 73 (2006) ("In general, the relative rankings of the 14 evaluated offenses made by different social groups within this sample [of Palestinians and Israelis] proved relatively stable . . . .").

${ }^{89}$ Mordechai Kremnitzer \& Khalid Ghanayim, Proportionality and the Aggressor's Culpability in SelfDefense, 39 Tulsa L. REV. 875, 893 (2004).

90 MatThew LippMan, SeAn MGCONVILle \& Mordechia Yerushalmi, ISLAMic Griminal LAW AND PROGEDURE: AN INTRODUCTION 56 (1988).

91 Special Rapporteur on the Promotion and Protection of Human Rights, Prevention of Human Rights Violations Committed with Small Arms and Light Weapons in Accordance with Sub-Commission Resolution 2002/25, ๆ 26, U.N. Doc.A/HRC/Sub.1/58/27 (July 27, 2006), available at

http://www.unhcr.org/cgibin/texis/vtx/refworld/rwmain?page=search\&amp;docid=45c30b560\&amp;skip=0\&amp;query $=$ barbara $\% 20$ frey (citation markers omitted). Even the proportionality requirement - perhaps the most controversial part of the American formulation - has been embraced in some form or another across many different cultures. For example, in Germany and Russia, where formerly "the 
In other words, Article 51 imposes limits on the use of defensive force that many if not most members of the United Nations would not impose in their own domestic law.

\section{Do People Have Different Intuitions of Justice About the Use of Force Between States than They Do Regarding the Use of Force Between Persons?}

Some might object that shared intuitions of justice regarding the use of defensive force by states differ from those regarding the use of force by individuals, and that the former are substantially more restrictive than the latter. ${ }^{92}$ However,

weight of authority oppose[d] articulating a formal test for limiting the right of self-defence"

George P. Fletcher, Proportionality and the Psychotic Aggressor: A Vignette in Comparative Criminal Theory, 8 ISR. L. REV. 367, 368 (1973), there has been a move toward substantive [proportionality] limits on even necessary acts of self-defense. Post-Soviet Russia has adopted Article 39 in its Criminal Code, which forbids acts of self-defense undertaken with disproportionate force. See UGOLOVNYI Kodeks Rossisskoi FederatsiI [UK RF] [Criminal Code] art. 39 (Russ.) ("The infliction of a harm that obviously does not correspond to the nature and the degree of threatened danger, nor to the circumstances under which the danger was removed, when equal or more considerable harm was done to the interests than the harm averted, shall be deemed to be in excess of extreme necessity."). Similarly, in Germany, "so-called 'socio-ethical limits' (sozialethische Einschränkungen) on self-defence have been introduced into the legal framework." T. Markus Funk, Justifying Fustifications, 19 OXFORD J. LEGAL STUD. 631, 640 (1999). Conversely, in countries that seem to have been moving away from American understandings of proportionality "in favor of clear rules that ordinary people can understand and apply," efforts have not sought to challenge the idea of proportionality per se but rather "the way the balance has been struck." Renee Lettow Lerner, The Worldwide Popular Revolt against Proportionality in Self-Defense Law, 2 J. L. ECON. \& POL'Y 331, 335 (2006).

92 One might also argue that people simply do not have any intuitions of justice regarding defensive force in conflicts between states. A quick glance at the public discourse regarding international conflicts would seem to make this claim implausible; people regularly make claims about the injustice of one use of force or another, including situations involving defensive force. The psychological literature on entitativity explains that people tend to personify a group, especially if the group is seen as having common traits and common goals, characteristics typical of states. See, e.g., Lawrence M. Solan, Private Language, Public Laws: The Central Role of Legislative Intent in Statutory Interpretation, 93 GEO. L.J. 427, 437-50 (2005); the writings of Bertran Malle, located at Scott Pious, Bertram F. Malle, Social Psychology Network (Nov. 27, 2011), http://malle.socialpsychology.org/; and the writings of Jim Sherman, located at Scott Pious, fim Sherman, Social Psychology Network (Jan. 20, 2010),

http://jim.sherman.socialpsychology.org/. Further, negative groups — such as unlawful aggressors - are seen as more highly entitative - that is, more likely to be personified, $i d$., thereby triggering people's intuitions of justice regarding the propriety of their use of force. Personification of the attacking state makes it that much more likely that the intended victim state will be similarly personified. 
we are aware of no evidence that suggests that people have two different sets of moral intuitions regarding the justice of defensive force, one for individuals and one for states. Indeed, we are not the first to criticize international law rules based on criminal law principles, or to argue that the same intuitions apply across contexts. ${ }^{93}$

To be fair, it is true that the use of defensive force by states often harms both unlawful aggressors and innocent non-aggressors (i.e., civilians), while this is less commonly the case in the domestic criminal law context. However, it does not follow that the intuitions of justice embodied in criminal law principles are inapplicable to the use of force by states, or that international law rules should be more restrictive than criminal law rules. In domestic criminal law, one may not purposely kill non-aggressors; one may knowingly harm non-aggressors only when this is the only way to prevent a greater evil; and one may only impose a substantial risk of harm on non-aggressors when this risk is justifiable in light of the result one seeks to achieve. ${ }^{94}$ These criminal law principles are virtually identical to the international law principles of distinction, necessity, and proportionality that are designed to regulate the use of force by states in order to protect innocent civilians. ${ }^{95}$ That these shared legal principles are rooted in shared moral intuitions is suggested by their systematic exposition in traditional and contemporary just war theory. ${ }^{96}$ If international law imposes additional restrictions on the use of force by states, then such restrictions are most likely based not on a different set of intuitions of justice but rather on utilitarian considerations, such as those discussed in the next section.

\section{Does International Law Deliberately Sacrifice Justice for the Sake of Peace?}

The UN Charter was intended both "to save succeeding generations from the scourge of war" and "to establish conditions under which justice . . . can be

\footnotetext{
93 See, e.g., Fletcher \& OHLin, supra note 55.

94 See, e.g., R. v. Dudley and Stephens, 14 Q.B.D. 273 (1884) (holding it unjustifiable to kill a nonaggressor as an intended means of preventing greater harm to others); MODEL PENAL CODE, supra note $18, \S 3.02 \mathrm{cmt}$. at 14-15 (finding it justifiable to harm a non-aggressor as a foreseeable sideeffect of preventing greater harm to others); see also id. $\S 2.02(2)(\mathrm{c})$ (defining recklessness as taking a substantial and unjustifiable risk) and $\S 2.10(1)$ (defining recklessly causing the death of another human being as criminal homicide).

95 See, e.g. , JeAn-Marie Henckaerts \& Louise Doswald-BeGK, Gustomary International HUMANITARIAN LAW 3, 46, 51(2005).

96 See, e.g., Michael Walzer, JUst and UnJust Wars ch. 9 (1977).
} 
maintained." 97 It is therefore possible that the drafters of Article 51 deliberately sacrificed justice for the sake of peace. In other words, the drafters of Article 51 might have expected victim states to suffer unjust aggression rather than respond with defensive force, with the ultimate goal of reducing overall violence in international affairs. While the prevention of armed conflict must be a central goal of international law, justice and peace need not be competing values. Indeed, international law can best maintain peace by doing justice.

As we have argued above, international law can most effectively prevent conflict if it is voluntarily obeyed by states, and international law will only be voluntarily obeyed by states if it is perceived to be morally legitimate. It is possible to compel adherence to unjust rules, but only where there exists an effective coercive mechanism devoted to that goal, which international law does not have. Without an effective international police force, international law must gain compliance with its rules primarily through its normative influence, the very influence that international law fritters away by adopting unjust rules. ${ }^{98}$

Sadly, international law gains nothing in exchange for its loss of moral credibility. Victim states that want to obey international law may do so to their own detriment and to the advantage of aggressor states. By contrast, aggressor states that have no inclination to obey international law will target law-abiding states and hide behind the unjust rules. In other words, unjust international law rules will avoid the use of force only by law-abiding states, not by unlawful aggressors. The restraint that international law induces in victims only serves to encourage unlawful aggressors and to give them significant tactical advantages over their victims. Ultimately, states that are inclined to obey international law, but that come to view its rules as unjust, will begin to question the moral credibility of international law and will become increasingly unreceptive to its normative influence. Advantaging unlawful aggressors and alienating those initially inclined to follow the law is hardly a successful formula for reducing the use of force.

It is true that aggressor states often portray themselves as victims, and one might argue, then, that broadening the authorization of defensive force might invite abuse and result in unnecessary conflict. However, states that are willing to misrepresent the facts of a given situation in order to conceal unlawful aggression

${ }^{97}$ UN Charter, Preamble.

${ }^{98}$ Note that international law can also gain compliance by harnessing the coercive power of victim states and their allies. See infra Part V.C. 
will do so no matter what set of defensive force rules are applicable. Unjust rules do not avoid the problem, but only serve to further advantage aggressors and disadvantage victims. Moreover, as Part IV.B demonstrates, it is possible to have clear rules about when force is justified in self-defense. The vagueness and ambiguity in current international law can be corrected.

To conclude, the enormous intuitive support for the use of defensive force against unlawful aggression goes even beyond what current domestic criminal law authorizes. International law rules, which impose even greater limits on defensive force than domestic criminal law, are likely to be perceived as seriously unjust. That reputation for injustice inevitably will undermine international law's longterm ability to gain compliance and reduce aggression.

\section{Implications for the Interpretation and Reform of International Law}

Part II discusses a variety of unjust international law limitations on the use of defensive force. In Section A below, we offer alterative interpretations of existing international law texts that would reach more defensible positions. However, re-interpretation alone can go only so far. Some problematic aspects of current international law cannot be corrected without substantive legal change. Section B, therefore, offers a proposal for reform of existing law. Until reform is possible, however, the re-interpretations proposed in Section A may be the only stopgap measure available.

\section{A. Alternative Interpretations of Existing International Law Texts}

For each of the improper limitations we objected to in Part II, we examine the possibility of alterative interpretations of international law.

1. Permit Necessary and Proportionate Defensive Force Against Deadly and Destructive Uses of Unlawful Armed Force

With respect to the threshold for the lawful use of defensive force under the UN Charter, we believe that a more permissive but still plausible interpretation of Article 51 should replace the more restrictive interpretation offered by the ICJ. While Article 2(4) of the UN Charter prohibits "the threat or use of force," Article 51 permits the use of force in self-defense, but only against an "armed attack." Ordinary principles of legal interpretation tell us that when different terms are used to describe similar phenomena, a different meaning is intended. As discussed in Part II, the ICJ has held that "armed attack[s]" form a 
subset of "use[s] of force," namely, those whose scope and effects exceed an unspecified threshold of magnitude or seriousness. While this dichotomy is plausible as a matter of textual interpretation, it must be applied with an eye toward the practical consequences of drawing the line in one place rather than another. States may use illegal force below the threshold without becoming liable to defensive force and with limited exposure to international sanctions. States suffering from illegal force below the threshold must either respond with force and thereby break the law or place their hopes in international mechanisms that will likely disappoint them. Much depends, therefore, on how broadly or narrowly international law construes the phrase "armed attack."

It is for this reason that some writers have argued that international law should construe the category of "armed attack" more broadly while construing the category of mere "use[s] of force" more narrowly. ${ }^{99}$ On this view, the class of uses of force that do not constitute an armed attack should be limited to de minimis infringements of state sovereignty. As one scholar observes, "agents of [one state] may break into a . . . diplomatic bag [of another state] or detain a[nother state's] ship in circumstances disallowed by international law. In both instances, a modicum of force must be posited, yet no armed attack can be alleged to have occurred." 100 Dinstein proposes that a use of force constitutes an armed attack if it causes or risks causing "serious consequences, epitomized by territorial intrusions, human casualties or considerable destruction of property." 101 We support this view that any illegal armed force that risks serious loss of lives or territory should trigger a state's right to resort to defensive force, subject to the jus ad bellum restrictions of necessity and proportionality as well as the principles of jus in bello.

This more practical reading of the UN Charter's "armed attack" provision would allow victim nations greater flexibility in defending themselves from illegal force, accruing the benefits discussed in Part III. Conferring a broader right of self-defense on victim nations would not only bring international law into alignment with accepted standards governing interpersonal conduct, but would bring increased stability to international relations.

\footnotetext{
${ }^{99}$ See, e.g., Dinstein, supra note 17, at 193.

${ }^{100} \mathrm{Id}$.

${ }^{101} I d$.
} 
2. Permit Necessary and Proportionate Defensive Force Against Armed Groups Operating from the Territory of Another State

As we have seen, the ICJ has suggested, and leading commentators have asserted, that the use of armed force by an armed group does not constitute an "armed attack" within the meaning of Article 51 unless the group was sent by a state or its use of armed force was effectively controlled by a state. If such a limitation on the phrase "armed attack" is accepted, then it follows that Article 51 as a whole does not permit defensive force in response to an armed attack carried out by nonstate actors operating from the territory of another state but not under the direction or control of that state. ${ }^{102}$ However, as Judge Higgins has cogently observed, "[t] here is, with respect, nothing in the text of Article 51 that thus stipulates that self-defence is available only when an armed attack is made by a State." 103 Article 51 says simply that states may use defensive force "if an armed attack occurs" and does not require that the armed attack be launched, directed, or controlled by a state. The notion that Article 51 permits self-defense only against a subset of armed attacks (namely, those that are launched, directed, or controlled by a state) has no basis in the text of the UN Charter, principles of justice, or considerations of sound policy.

One may argue that because Article 2(4) prohibits the use of force against the territorial integrity of another state and because Article 51 is an exception to Article 2(4), Article 51 must refer only to an armed attack by the state whose territorial integrity will be infringed by the use of defensive force. But this is not a particularly persuasive argument, and becomes even less so in light of the significant drawbacks it introduces, discussed in Part II. In any case, it is equally (or perhaps even more) plausible to conclude that any armed attack that originates from the territory of another state justifies the use of defensive force- subject to the constraints of necessity and proportionality - against the source of the attack, even if such defensive force involves the infringement of another state's territorial integrity. The territorial location of an attacker makes little difference to the victim under attack, after all. It may well be that an attack could be carried out by actors who are unaffiliated with, or possibly only tolerated by, the state from which they operate. In that situation, it would be patently unjust to hold that the victim state could not act in its own defense, notwithstanding the host state's lack of relation to the aggressors. There is no sound reason, then, that the current uncertainty

102 See supra Part II.A.

${ }^{103}$ Legal Consequences of the Construction of a Wall in the Occupied Palestinian Territory, Advisory Opinion, 2004 ICJ 136, 215 (separate opinion of Judge Higgins) (emphasis omitted). 
regarding the application of Article 51 to nonstate actors cannot be resolved in favor of permitting necessary and proportionate defensive force against nonstate actors operating from the territory of another state.

Importantly, a state that uses defensive force against aggressors operating from within the territory of an innocent third party state must plead both selfdefense against the aggressor and necessity with respect to the territorial intrusion. As we noted in Part II.B, both parties to the Caroline incident seem to have assumed that force could be used against armed groups operating from the territory of another state so long as the requirements of necessity and proportionality were met. In an apparent effort to reconcile the iconic precedent of the Caroline incident with the ICJ's interpretation of the UN Charter, the International Law Commission (ILC) asserts that the British use of force in the Caroline incident should be classified not as an exercise of self-defense against a non-state actor but as a response to a situation of "necessity." 104 The ILC goes on to state that necessity precludes responsibility for a State's violation of international law that "(a) is the only way for the State to safeguard an essential interest against a grave and imminent peril; and (b) does not seriously impair an essential interest of the State or States towards which the obligation exists, or of the international community as a whole." 105 Here the Commission is at most half right. The British infringement of the territorial integrity of the United States may indeed be best justified in terms of necessity. However, the British use of force against the Caroline itself can only be justified in terms of self-defense. Similarly, in domestic criminal law, if a victim, in order to repel an attack by an aggressor, trespasses onto the property of an innocent third party (for instance because the aggressor is shooting from inside the house of the innocent third party) the victim will plead necessity with respect to the trespass but will plead self-defense with respect to the use of defensive force. International law should be interpreted to ensure that such a combination of defenses is available to states that use defensive force against aggressors operating on the territory of an innocent third party state.

\footnotetext{
${ }^{104}$ Report of the International Law Commission on the Work of Its Fifty-Third Session, U.N. GAOR International Law Commission, 55th Sess., at 81, U.N. Doc. A/56/10 (2001), available at http://untreaty.un.org/ilc/texts/instruments/english/commentaries/9_6_2001.pdf.

105 Id. at 80 .
} 
3. Permit Necessary and Proportionate Defensive Force Against Imminent Unlawful Aggression

Although we are tempted to interpret the UN Charter to permit necessary and proportionate defensive force against armed attacks that have not yet begun, we are forced to conclude that such an interpretation is not sustainable and that substantive reform is necessary. While a plain reading of Article 51 suggests that states may only use defensive force against attacks which are either ongoing or in their early stages, many states, UN officials, and international law scholars have offered interpretations of the UN Charter that would permit the use of force to preempt an imminent armed attack. ${ }^{106}$ The primary textual argument for this position is that Article 51 recognizes the "inherent right of . . . self-defense" of each member state, and the term "inherent" indicates that the UN Charter preserves the right of self-defense as it existed in customary international law prior to the signing of the UN Charter. ${ }^{107}$ Pre-Charter customary international law, in turn, permitted a state to use defensive force if it confronted "a necessity of selfdefense, instant, overwhelming, leaving no choice of means, and no moment for deliberation." 108 Therefore, the argument runs, the Charter itself, by recognizing the "inherent" right of self-defense, permits the use of force to preempt an imminent attack, subject only to the traditional limits of necessity and proportionality imposed by customary international law.

One problem with this textual argument is that Article 51 states that "[n] othing in the present Charter shall impair the inherent right of . . . self-defense if an armed attack occurs." The text of Article 51 does not indicate whether the Charter impairs the "inherent" (pre-Charter) right of self-defense before an armed attack occurs. If Article 2(4) contains a general prohibition on the use of force and if Article 51 carves out an exception to that prohibition, ordinary cannons of legal interpretation dictate that the exception should be interpreted narrowly and that

\footnotetext{
106 See, e.g., Testimony of Attorney-General Goldsmith Before the British House of Lords, April 21, 2004, in O'CONnELL, supra note 23, at 293-95; Kofi Annan, Report of the Secretary-General, In Larger Freedom: Towards Development, Security, and Human Rights for All, U.N.G.A. A/59/2005, March 21, 2005, at 33 ("Imminent threats are fully covered by Article 51, which safeguards the inherent right of sovereign states to defend themselves against armed attack. Lawyers have long recognized that this covers an imminent attack as well as one that has already happened."); D.W. BOWETT, SELF-DEFENSE IN INTERNATIONAL LAW 187-92 (1958).

107 See, e.g., GRAY, supra note 5, at 98-99; Anthony Clark Arend, International Law and the Preemptive Use of Force, 26 WASH. Q. 89, 92 (2003).

108 Letter from Daniel Webster to Henry Fox (April 24, 1841), 29 BRITISH AND Foreign STATE PAPERS 1129, 1138 (1840-41).
} 
the use of force to preempt an imminent attack falls under the general prohibition. ${ }^{109}$ Similarly, while Article 2(4) prohibits "the threat or use of force," Article 51 recognizes a right to self-defense only against the use of force (or, perhaps, the subset of uses of force that constitute armed attacks). The fact that the drafters of Article 51 did not recognize a right to self-defense against the threat of force suggests that they did not accept the existence of such a right.

A second important textual argument in support of the use of defensive force against an imminent attack arises from the claim that such defensive force does not violate Article 2(4)'s general prohibition against "the threat or use of force against the territorial sovereignty or political independence of any state." This argument asserts that a state does not violate Article 2(4) unless it attempts to seize territory or depose another government. Since a state seeking to preempt an imminent attack need not attempt to occupy or govern the state planning an imminent attack, it would seem that the defending state does not violate Article 2(4). ${ }^{110}$

This argument may prove too much. Article 2(4) must prohibit the threat or use of force to punish another state for past wrongs or slights, to humiliate its leaders, to weaken its economy, or for an indefinite number of reasons other than territorial conquest or regime change. True, Article 2(4) also prohibits "the threat or use of force ... in any other manner inconsistent with the Purposes of the United Nations." It could be argued that this catch-all provision precludes the threat or use of force solely to injure another state but does not preclude the threat or use of force to prevent an imminent attack. The difficulty with this reading is that either Article 51 specifies the exclusive conditions under which the threat or use of force is "Пconsistent with the Purposes of the United Nations" or it does not. If it does, then the use of force is permissible only "if an armed attack occurs." If it does not, then instead of settling the international law governing the use of force, the UN Charter simply introduces a new element of uncertainty, namely whether a given use of force is "consistent with the Purposes of the United Nations." While permitting the use of force against imminent attacks is an important goal, it should not be secured at the expense of the clarity of the legal regime as a whole.

\footnotetext{
109 See, e.g., Gray, supra note 5, at 98-99. See also Antonio Cassese, International GriminaL LAW 290 (2d ed. 2008) (referring to "the general principle of interpretation whereby rules setting forth exceptions to general prohibitions must be strictly construed").

110 See, e.g., BOWETT, supra note 106, at 188.
} 
Finally, it is possible to concede that the UN Charter forbids defensive force to prevent imminent attacks but to argue that the Charter has been superseded by a new customary international law norm permitting such defensive force. Such an argument is difficult to sustain, since it is not clear that states have explicitly relied on this norm to justify their behavior. ${ }^{111}$ It follows that an international legal norm permitting defensive force to prevent imminent attacks still needs to be clearly articulated. Despite the best efforts of revisionist commentators, the legality of using force to preempt imminent attacks cannot be reconciled with a fair reading of the UN Charter.

4. Permit Necessary and Proportionate Defensive Force Against Unlawful Aggression that is Planned But Not Yet Imminent

We know of no plausible interpretation of the UN Charter that would authorize the use of necessary and proportionate force to defend against a planned attack that is not yet imminent. As discussed immediately above, there is a colorable argument that Article 51 incorporates a pre-Charter customary international law norm permitting necessary and proportionate force to prevent an imminent armed attack. However, there is a broad consensus among scholars that customary international law did not recognize a right to use force to prevent a planned attack that is not yet imminent, despite the recurrent use of such force throughout military history. ${ }^{112}$ Furthermore, there is no evidence that a customary norm permitting force against a non-imminent attack has emerged in the years since the passage of the Charter.

Nonetheless, we believe that defensive force should be legally permissible if (a) there is clear and convincing evidence that (i) the political and military leadership of another state plans to use illegal force and (ii) that state has taken

\footnotetext{
111 See, e.g., DinsteIN, supra note 17, at 183-87 (observing that states that use force almost always claim to be responding to an incipient or ongoing armed attack rather than anticipating a future armed attack); GRAY, supra note 5, at 111-15 (same).

112 See, e.g., DinSTEIN, supra note 17, at 184 (arguing that "the right of self-defense consolidated only upon the prohibition of the use of force between States. That prohibition was first evinced in the Kellogg-Briand Pact of 1928 and reiterated, in clearer and broader terms, in Article 2(4) of the Charter in 1945. What preventive war of self-defense was unleashed between 1928 and 1945?"). Indeed, when the United States in 2002 announced a policy of using force to prevent nonimminent terrorist attacks it acknowledged that such a policy represents a departure from existing customary international law. See The White House, National Security Strategy of the UNITED STATES OF AMERICA 15 (2002), available at http://merln.ndu.edu/whitepapers/USnss2002.pdf.
} 
substantial steps or performed overt acts in furtherance of its plans; (b) the use of force is immediately necessary to effectively prevent the use of illegal force; and (c) the defensive force used is proportionate to the harm that would be caused by the planned illegal attack.

The clear and convincing evidence called for by our proposal will no doubt prove difficult to gather, even through sophisticated espionage and intelligence operations. However, it is not our intention to provide states with a license to use force whenever they feel threatened. We believe that the level of evidence a state must acquire before using force should depend on the relative costs of error. One might initially think that it is equally bad for State A to suffer an act of aggression by State B as for State A to launch an attack of comparable scale and gravity against State B in the mistaken belief that State B is planning to attack State A. If that were the case, then a lower standard of 'reasonable belief,' 'preponderance of the evidence,' or 'more likely than not' might be appropriate. However, we believe that a higher standard of certainty is warranted, both on the moral ground that doing harm is generally worse than allowing harm and on the pragmatic ground that any lower standard would be too susceptible to error and abuse.

Importantly, in this context the plan to use illegal force will often take the form of a conditional intention to use illegal force if and only if certain intervening events occur. Specifically, the conditions under which the leadership of the other state will carry out their intention may involve the acquisition of the capacity to carry out an attack or the capacity to deter a forceful response to an attack. In such cases, states may use defensive force to prevent other states from satisfying the condition attached to their intention to use illegal force. For instance, if there was sufficient evidence that the Nazi leadership intended to use the French ships docked at Mers el-Kebir to stage future attacks against the U.K. then the U.K. was prima facie justified in using proportionate force to prevent the Nazis from acquiring those ships. ${ }^{13}$ At the same time, we reject the use of force by one state simply to maintain its own military superiority by preventing another state from acquiring greater military power. A state may use force to prevent force that another state actually plans to use, including force that it plans to use only after

113 Obviously, this case arose within a broader war in which the Nazi intention to use force against the U.K. was safe to presume. 
certain intervening events occur. However, a state may not use force simply out of fear that another state may one day form a plan to use unlawful force against it. ${ }^{114}$

On our proposed view, the U.S. invasion of Iraq in 2003 would not have been a permissible use of defensive force even if there had been clear and convincing evidence that the Iraqi government possessed illegal weapons of mass destruction or was illegally developing such weapons. There would have to have been, in addition, clear and convincing evidence that the Iraqi government planned to use such weapons in an attack on the United States or another country. If I learn that my neighbor has an illegal firearm in his house, I cannot on that basis break into his house and assault or kill my neighbor and claim selfdefense. I must show, in addition, that such force was immediately necessary to prevent my neighbor from using that illegal firearm against me or another person. In international law, too, there is a difference between law enforcement and selfdefense, and we do not here advocate a right of individual states to use force to compel other states to obey international law. One state's violation of international law only justifies the unilateral use of force by another state if the violation consists in an actual, imminent, or planned attack against the second state.

We recognize that unlawful aggressors may try to claim that their use of force is in fact defensive and intended to prevent an imminent or planned attack. We also agree that it can be justifiable to legally circumscribe the use of a moral right in order to prevent its abuse. However, we do not believe that it is appropriate to prohibit victim states from using defensive force against planned attacks in order to prevent aggressor states from fraudulently claiming that their aggression is in fact defensive. States that fail to convince the international community that their use of force was necessary to prevent a planned attack will suffer whatever legal, diplomatic, or reputational consequences the international system is capable of imposing. Mere assertion is not enough, and reliance on fabricated or exaggerated evidence invites public scrutiny and, eventually, condemnation. For example, the Israeli attack on Iraq's Osirak nuclear reactor on June 7, 1981, prompted widespread condemnation, including in both the UN Security Council and the General Assembly. ${ }^{15}$ The fact that Israel was protected

\footnotetext{
${ }^{114}$ Indeed, pursuant to the necessity constraint, states may not even use force to prevent force that another state conditionally intends to use if the conditions under which the other state would carry out its intention (for instance, the acquisition of weapons of mass destruction) cannot be reasonably expected to occur.

115 See FRANCK, supra note 12, at 105-07.
} 
from more serious consequences is a result of the political structure of the United Nations, not the substantive rules of international law. Moreover, we submit that the strongest basis for condemnation was not that an Iraqi attack was not ongoing or even that an Iraqi attack was not imminent but rather that there was no clear and convincing evidence that a future Iraqi attack was planned. ${ }^{116}$ We see no reason why international law cannot continue to distinguish between legitimate uses and illegitimate abuses of the right to use necessary force to prevent planned attacks. The fact that international condemnation often fails to deter unlawful aggression hardly justifies condemnation of victim states for their legitimate use of defensive force. Moreover, if international institutions improve their capacity to enforce international law, as we hope, then they should be able to enforce the rule we propose as readily as a rule permitting the use of defensive force against an imminent attack.

We emphasize that the unnecessary use of force is always illegitimate; that the reasonable possibility of effective international intervention or negotiated settlement negates the necessity to use force; and that such peaceful methods of dispute resolution are typically available in most conflicts. We also reiterate that belief in the necessity to use preventative force will often be unreasonable: based on speculation rather than reliable evidence, reacting to imputed motives rather than clear intentions, responding to subjective insecurity rather than objective danger. Preventive force based on such unreasonable beliefs is unjustified and should be subject to censure and sanction. However, where preventative force is demonstrably necessary, it should be permitted under international law.

\section{B. Reform Proposal}

As the discussion above makes clear, the improper limitations on the use of defensive force that we objected to in Part II cannot all be avoided through pragmatic reinterpretation of Article 51. For example, as noted above, the interpretations offered in support of the use of force to defend against an imminent attack, while admirable, are ultimately unpersuasive. Furthermore, we know of no plausible interpretation of the UN Charter that would support the use of force necessary to successfully defend against unlawful aggression that is not imminent. Perhaps more importantly, relying upon a collection of disputed interpretations hardly provides the kind of clarity that international law should

\footnotetext{
116 As noted above, states may not use force to prevent rivals from enhancing their technological or military capability absent sufficient evidence that a rival plans to launch an attack upon acquiring such enhanced capability.
} 
provide on matters of force and defense.

We therefore urge the adoption of a clear legal rule governing the use of defensive force, whether through a UN Security Council Resolution or an international convention, that will avoid the defects of Article 51. The legal rule will over time form the basis of customary international law that will supersede the UN Charter. We would draft that rule as follows:

Use of Force in Self-Defense

(1) Defensive Force. A state may use force to prevent unlawful aggression, before or during its occurrence, provided that such force is:

(a) immediately necessary to prevent such unlawful aggression, and

(b) proportionate to the harm that such unlawful aggression would cause if not prevented.

(2) "Unlawful Aggression." For the purposes of this rule, "unlawful aggression" means the use of armed force by a state or armed group that infringes the territorial integrity or political independence of a state and that causes or risks substantial loss of life, physical injury, or damage to property.

The proposed language is designed to discard the improper limitations discussed above by clearly stating that any deadly or destructive use of armed force triggers the right of self-defense; by clearly permitting defensive force against both states and armed groups; and by clearly permitting the use of defensive force to prevent acts of aggression before they occur or while they are occurring as long as such force is immediately necessary for effective defense. The arcane limitations placed on defensive force by the ICJ's interpretations of Article 51 are wiped away, replaced by the customary international law principles of necessity and proportionality that have a long legal pedigree and intuitive moral appeal.

\section{The Enforcement Limitations and Special Deterrence Needs that Distinguish International Law from Criminal Law}

While there is an obvious parallel between the functions of international law and criminal law, as Part I suggests, there also are some important differences, most importantly the difference between the existing law enforcement mechanisms within the two regimes. 


\section{A. The Absence of an Effective Enforcement Mechanism in International Law}

Criminal law rules governing the use of force exist in the context of a functioning criminal justice system of police, prosecutors, courts, and corrections to which one may reasonably be required to defer as a source of security and justice. While there continue to be admirable efforts toward creating an effective international law enforcement and adjudication system, and while such a system might well be created sometime in the future, at present there is no such central authority.

The United Nations Security Council can authorize the use of force to maintain international peace and security, but authorization of such a "police action" can be blocked by any one of the Security Council's five permanent members or by seven of its ten elected members, and member states can refuse to provide military or financial support for an authorized action. Moreover, the process of obtaining such a resolution is both burdensome and time consuming. In the 64 years since the creation of the United Nations in 1945, such resolutions have been passed with respect to only two state-to-state conflicts, ${ }^{117}$ a small fraction of the situations in which states suffered or are suffering unlawful aggression of one kind or another.

Similarly, the International Criminal Court (ICC) cannot assert jurisdiction over the crime of aggression because the Rome Statute, which establishes and limits the ICC's jurisdiction, still does not contain a definition of that offense. ${ }^{18}$ The offense definition contained in the Aggression Resolution will not become part of the Rome Statute until a majority of States Parties adopts it as such, which it cannot do until January 2017 at the earliest. ${ }^{119}$ Even then, absent referral of a situation to the ICG by the Security Council, the ICG will have jurisdiction only over acts of aggression committed by a State Party. ${ }^{120}$ Most

117 See S.C. Res. 82, U.N. Doc. S/RES/1501 (June 25, 1950); S.G. Res. 83, U.N. Doc. S/1511 (June 27,1950); S.C. Res. 84, U.N. Doc. S/RES/1588 (July 7, 1950) (authorizing the use of force to compel North Korean withdrawal from South Korea); S.C. Res. 678, U.N. Doc. S/RES/0678 (Nov. 29, 1990) (authorizing the use of force to compel Iraqi withdrawal from Kuwait). See also S.C. Res. 794, U.N. Doc. S/RES/794 (Dec. 3,1992) (authorizing the use of force to stem civil war in Somalia); S.C. Res. 1244, U.N. Doc. S/RES 1244 (June 10, 1999) (authorizing the use of force to protect the former Yugoslav province of Kosovo).

118 See Rome Statute of the International Criminal Court, art. 5(2), July 17, 1998, U.N. Doc. A/CONF.183/9 [hereinafter Rome Statute].

119 See Aggression Resolution, supra note 2, Annex I, art. 15 bis (3).

${ }^{120} I d$. Annex I, art. 15 bis (5). 
disturbingly, even States Parties may avoid prosecution for aggression simply by filing a declaration with the ICG Registrar that it does not accept the ICG's jurisdiction with respect to aggression. ${ }^{121}$ Put the other way around, countries may avoid prosecution for aggression simply by not becoming parties to the Rome Statute; or they may become States Parties but opt out of the ICG's jurisdiction over the crime of aggression. Finally, any prosecution by the ICG can be indefinitely deferred by Security Council Resolution. ${ }^{122}$ Prosecutions before the ICG will therefore depend, at least in part, on the same unreliable UN system discussed above. As a result, there simply is not now, nor is there likely to be for the foreseeable future, a reliable central enforcement mechanism for international law that states can rely upon as a realistic and effective alternative to their own use of defensive force. ${ }^{123}$

\section{B. Implications for International Use of Force Rules}

The absence of an effective law enforcement, adjudication, and punishment system for international law has important implications for the formulation of its rules governing the use of defensive force. Consider, for example, that most modern American criminal codes provide that, before using deadly force, a defender must first retreat or must give up the thing sought by the aggressor. As the Model Code drafters explain their retreat rule:

To the argument that the retreat rule cedes the field to any group of bullies prepared to make a show of deadly force, the answer has been that the proper and sufficient remedy is not a trial of strength but rather a complaint to the police. If this forgoes a private sanction that might operate as a deterrent to aggressors, it does so in reliance on the adequacy of the public sanctions . . . 124

This makes perfect sense in the criminal law context: While the original unlawful aggression is injurious and condemnable, the criminal law judges that, on balance, the defender ought to retreat in the face of aggression because society will be better off in the long-run if the victim defers to the society's criminal justice

\footnotetext{
${ }^{121} I d$. Annex I, art. 15 bis (4).

122 See Rome Statute, supra note 118, art. 16.

${ }^{123}$ Note that civil damages for acts of aggression can be obtained through the International Court of Justice, arbitral tribunals, or negotiated settlement, but these are all ultimately consensual processes.

124 See, e.g., Model Penal Code, supra note 18, § $3.04 \mathrm{cmt}$ at 54.
} 
system. It is left to the criminal justice system, with its police, courts, and corrections system, to do justice and to prevent future aggression.

International law, by contrast, can hardly craft its liability rules based on the assumption that a defender should defer to a central enforcement authority. To demand restraint without an effective enforcement system is to leave the defender and the larger community without justice in the case at hand and without a means to avoid unlawful aggression in the future.

Thus, it would be wrong for international law to track limitations on the use of force found in domestic criminal law rules that are justified by a policy of deferring to a centralized enforcement authority. Yet, this is exactly what international law does. It adopts certain criminal law limitations on responses to unlawful aggression even though one of the crucial assumptions underlying them - the existence of an effective enforcement authority - does not exist. The problem that designers of international law use of force rules must address is not that with which criminal code drafters are faced, but rather is in some ways closer to that of a system designer in a lawless society: in the absence of an effective enforcement system, how should we set legal rules so as to maximize justice and stability?

What can a system designer do in the international law context where no reliable system of coercive enforcement is possible in the foreseeable future? How can an international law system gain the compliance needed to maintain international order and justice, without a centralized body to enforce its rules?

While the absence of an enforcement mechanism suggests a fundamental problem, all is not lost. Modern punishment theory offers some ideas that can be useful. Two kinds of approaches might gain compliance without reliance upon a centralized coercive power, but each requires a formulation of international use of force rules quite different from those in existence today.

First, international law rules might be formulated to rely upon normative rather than coercive forces to maintain order. That means crafting rules that narrow rather than widen the gap between international law and people's moral intuitions. Parts III and IV have sketched the basic approach, the reasons for it, and its legal implications.

A second approach, which might be used in conjunction with the first or independently, is to structure international law rules so as to harness, in the 
service of international interests, the use of force by individual states in response to unlawful aggression.

\section{Use of Force by Individual States Against Unlaweful Aggressors as an International Law Enforcement Mechanism}

There does exist on the global stage sufficient coercive power to substantially reduce unlawful aggression. However, the power we refer to lies not with international institutions but in the hands of individual states. Could international law be formulated to harness the coercive power of states in the pursuit of international peace and security?

When modern punishment theory considers the problem of gaining compliance with criminal prohibitions, a common approach-indeed, the dominant approach of the last several decades - is to compel compliance through the threat of deterrent sanctions. One can imagine an approach in which the international law system designs its response-to-unlawful-force rules to provide a general deterrent threat against unlawful aggression.

A number of potential difficulties with this approach come quickly to mind. First, modern punishment theory has become increasingly skeptical of the effectiveness of general deterrence as a mechanism for compelling compliance with a set of specific conduct rules. Does that same skepticism apply in the international law context as well, or does the international context provide the special circumstances in which compliance through deterrence might actually work? Second, even if control through deterrence is feasible in the international context, how could international law hope to control deterrent threats of force by individual states so as to promote international interests?

\section{The Potential for Effective Deterrence in the International Context}

There are good reasons to be skeptical about the effectiveness of deterrent threats as a means of controlling conduct. As has been noted in detail elsewhere, ${ }^{125}$ relying upon general deterrence as the principle for distributing liability and punishment in a criminal justice system is problematic for a variety of reasons. A threat of punishment for violation of a conduct rule can have no effect unless the intended target is aware of the rule and of the threatened punishment. Unfortunately, in domestic criminal justice systems many offenders have limited

125 See Paul H. Robinson, Distributive PrinciPles, supra note 63, at chs. 3 \& 4. 
knowledge of criminal law rules and associated punishments, either directly or indirectly, and many who think they know the rules and punishments in fact have them wrong. ${ }^{126}$

The international context presents a more promising situation. States have the resources and typically the inclination to know both the international law rules governing their behavior as well as any sanctions that would attach. While the ambiguity of many aspects of international law can create special problems here, states nonetheless have the motivation and resources needed to learn both the applicable rules and the available sanctions.

A second hurdle for effective control through deterrence is found in the failure of individuals to rationally calculate their self-interest. In the criminal law context, the potential offenders most in need of deterrence unfortunately commonly suffer from one or more impairments of rational calculation. Alcohol or drug use, impulsiveness, mental disorders, fear, anger, group identification, and a variety of other characteristics and conditions tend to either distort the potential criminal's calculation of the costs and benefits of committing an offense or tend to distract the potential criminal from calculating future consequences at all. ${ }^{127}$

Again, the international context does not typically present the same problem. While there are no doubt examples of dictators who are mentally unbalanced or other instances of state decision-making that deviate from the state's rational self-interest, the level of rational calculation among states is likely to be dramatically higher than among potential criminal offenders in the domestic context.

Finally, even if the intended target of the deterrent threat knows of the rule and the threatened punishment and can and does rationally calculate what is in his or her best interest, there can be no deterrent effect unless that calculation in fact generates a conclusion in the calculator's mind that the cost of violating the conduct rule exceeds the benefit. In the domestic criminal law context, this is problematic for a variety of reasons, the most prominent of which may be the poor punishment rates for most offenses. It is not the actual punishment rate that matters, of course, but rather the perceived punishment rate, but in the criminal justice context both are so low for most offenses that the deterrent threat

${ }^{126} I d$. at $24-28$.

127 Id. at $28-32$. 
commonly lacks significant force. In competition to that, the benefit that commonly derives from the offense is usually obvious, certain, and immediate. ${ }^{128}$

In this one respect, the international situation may well share the domestic criminal justice situation, at least when one considers the likelihood of punishment by a weak or nonexistent central law enforcement authority. This is the point made in Part V.A. above. On the other hand, when one considers the possibility of a forceful response by the intended victim or other states acting on her behalf, the possibility of effective deterrence is more promising. With the proper formulation of international law rules, the likelihood of force in response to unjustified aggression may well prove sufficient to deter the aggression.

\section{Harnessing the Use of Force by Individual States to Deter Unlawful Aggression}

Assuming that a deterrent effect is possible in the international context, at least through the use of force by individual states, how could international law induce individual states to exercise their coercive power in furtherance of international interests? It might be realistic to think that a central international authority might put international interests first, but how realistic is it to think that an individual state would do the same?

What saves the day here for effective international law enforcement is the fact that an effective deterrent system does not necessarily depend upon selfsacrifice. Certainly the state being victimized by unlawfulness has adequate motivation to use force against the law-breaker. Additionally, other states may come to a victim's defense, either because of an alliance with the victim state or an enmity with the aggressor state. Finally, some states with no interest in a particular conflict may believe that resistance to unlawful aggression generally is in their long-term interest. Even weak states may face situations where the nature of the threat and its circumstances make a forceful response worthwhile. And, in this world of interlocking relationships, it is common for a weaker state to have allies or others who would help. Of course, if a victim state is attacked by a vastly more powerful aggressor and is unable to summon allies to its defense then the scope of its right of self-defense may make no difference to the outcome. But if a carefully broadened right of self-defense would deter some aggression then it is hardly a criticism that it will not deter all aggression.

128 Id. at $32-48$ 
The point here is that, to be effective, international law need not motivate victim states and others to use force against unlawful aggressors. It is enough that international law avoid interfering with and undermining the use of force against unlawful aggression that states otherwise may be motivated to provide. Unfortunately, as Part II has illustrated and Part VI will demonstrate further, current international law limitations on the use of responsive force affirmatively discourage force against unlawful aggression. The effect of these limitations is problematic for a variety of reasons.

First, and most obviously, international law rules limiting the use of force to repel or deter unlawful aggression have the unfortunate effect of encouraging such aggression by lowering its expected costs. Granted, when its security is at stake, a victim state often will defend itself even in violation of the unjust international law limitations, ${ }^{129}$ but any decrease in the probability of a forceful response will affect the balance of expected costs and benefits to the aggressor. At the margins, the existence of these limitations can make the difference in the aggressor's decision-making.

Further, and ironically, the effect of the current rules is to victimize most those states that publicly announce and demonstrate their commitment to following international law. A historically law-abiding state is a more attractive target for unlawful aggression because the aggressor can more reliably rely on the victim to adhere to international law limitations on responsive force. By contrast, states seen as willing to break current international law rules will be less attractive targets because potential aggressors will worry that those states may be willing to use defensive and deterrent force even if it violates international law limitations.

In this respect, the current international law rules are self-defeating. These rules penalize law-abiders and reward law-breakers, hardly a recipe for long-term stability or for building compliance with international law rules. Indeed, such a situation is problematic not only because it undermines effective deterrence but also because it tends to create a habit of law-breaking. By allowing states to legitimize law-breaking in those situations where international rules set unfair limitations, international law undermines its own credibility and thereby its ability to get compliance for those limitations on the use of force that are fair and just, as Part III details. By squandering its moral credibility generally, international law loses the only other mechanism (aside from deterrent force) that may gain compliance in the absence of an effective enforcement system.

${ }^{129}$ See, for example, the responses to unlawful aggression listed in the text at note 189 infra. 


\section{International Law Limitations on Effective Deterrence}

Part V discusses the absence of centralized enforcement in the international system and the resulting need for international law to rely upon the deterrent capacity of individual states to oppose unlawful aggression that international law institutions cannot themselves provide. Yet, as this Part documents, current international law limitations on the use of responsive force in fact undermine effective deterrence of unlawful aggression. For example, international law bars the use of force against states that support armed groups launching unlawful attacks. ${ }^{130}$ Similarly, international law so limits the use of defensive force that it appears to forbid the use of force against attackers in between their unlawful attacks. In this same vein, international law permits defensive force against the source of an armed attack but appears to forbid defensive force against supporters of unlawful aggression. Finally, international law prohibits the use of force against an unlawful attacker in order to deter further unlawful aggression in the future. These limitations bestow strategic advantages on unlawful aggressors and disadvantages on victims, while missing the opportunity to use the coercive force of victim states and their allies to help deter unlawful aggression. The right of self-defense should therefore be broader under international law than under domestic criminal law.

\section{A. Barring the Use of Force Against States Supporting Unlawful Aggression by Armed Groups}

The ICJ has held that the UN Charter's "armed attack" threshold forbids the use or threat of force against a state that, rather than launching an armed attack itself, gives sanctuary, weapons, or support to a third party that then launches armed attacks of its own. For instance, from 1979 to 1981, the Sandinista government of Nicaragua, in violation of international law, supplied arms and safe haven to insurgent forces seeking to overthrow the government of El Salvador. The ICJ denied that "the provision of arms to the opposition in another State constitutes an armed attack on that State."131 The Court held that, "[e]ven at a time when the arms flow was at its peak, and again assuming the participation of the Nicaraguan Government, that would not constitute such

\footnotetext{
130 As Part II.B, has already shown, international law seems to forbid attacks on the groups themselves when in the sanctuary of the supporting state.

131 Nicaragua, supra note 16, 9230.
} 
armed attack."132 Thus, according to the ICJ, El Salvador was barred from using any degree of force to end the Nicaraguan violation. ${ }^{133}$ The ICJ held that "while the concept of an armed attack includes the despatch by one state of armed bands into the territory of another, the supply of arms and other support to such bands cannot be equated with armed attack." 134

It is true that, under domestic criminal law, a neighborhood resident who gives sanctuary and support to burglars or home invaders who terrorize the neighborhood generally may not be met with defensive force by other neighborhood residents, even though the support itself is clearly illegal. But this domestic limitation on defensive force presupposes the existence of an effective police force that could be called to immediately put a stop to the aggression.

Consider the case of the Taliban regime that controlled Afghanistan from 1996 to 2001 and allowed its territory to be used by the Al Qaeda terrorist organization to train its operatives and plan attacks in other countries. Under international law, the use of force by an armed group will be imputed to a host state only if the state directs or exercises effective control over that specific use of force. ${ }^{135}$ But if a state avoids direct involvement with specific attacks but still provides its territory as a sanctuary, then the host state is not deemed responsible for the attacks and the victim state may not use force against it. This is so despite the fact that giving such sanctuary to armed groups is itself a violation of

\footnotetext{
132 Id.

133 The ICJ left open the possibility that El Salvador might have been justified in exercising "proportionate counter-measures" against Nicaragua, but it does not seem that these countermeasures include the use of force. Id. at 127. For instance, a state can respond to the use of force short of an armed attack with (i) nonforceful but illegal reprisals (e.g., breach of a bilateral treaty); (ii) legal but hostile retorsions (e.g., withdrawal of diplomats or imposition of economic sanctions); or (iii) appeal to international processes.

${ }^{134} I d$. 1247.

135 See, e.g., Report of the International Law Commission on the Work of Its Fifty-Third Session, U.N. GAOR International Law Commission, 55th Sess., art. 8, at 45, U.N. Doc. A/56/10 (2001) ("The conduct of a person or group of persons shall be considered an act of a State under international law if the person or group of persons is in fact acting on the instructions of, or under the direction or control of, that State in carrying out the conduct."). Note that the ICTY has suggested that overall control of an armed group is sufficient for state responsibility. See Prosecutor v. Tadic, Judgment, ICTY Case No. IT-94-1-A, Appeals Chamber, 1999, 38 ILM 1518, 1540-45. In that case, war crimes committed by a state-sponsored militia were attributed to the Serbian government despite the fact that there was no evidence of governmental control over the specific acts at issue.
} 
international law. ${ }^{136}$ According to most reports, the Taliban did not direct or exercise effective control over the 9/11 attacks, nor did they exercise overall control of $\mathrm{Al}$ Qaeda's operations or provide them with significant tactical or logistical support.

After the September 11, 2001, attacks were attributed to Al Qaeda, the Taliban government refused to extradite $\mathrm{Al}$ Qaeda members for trial in the United States. The United States rejected the Taliban's offer to prosecute Al Qaeda members in Afghanistan, and forcibly removed the Taliban from power. Although broadly endorsed by the international community, the removal of the Taliban appears to have been illegal under the UN Charter. Security Council Resolutions 1368 and 1373, which condemned the 9/11 attacks and called on states to suppress terrorist groups operating from their territory, did not authorize the use of force against the Taliban. ${ }^{137}$ Nor, according to the ICJ's past rulings, would the removal of the Taliban seem to constitute a legitimate exercise of selfdefense under international law. ${ }^{138}$

It does not take much imagination to see that these international law rules promote instability and injustice. International law allows states to support unlawful aggression by armed groups without fear of defensive force in response, so long as they avoid specific direction and control of the unlawful aggression. By shielding the support of unlawful aggression, international law only encourages the same - and undermines its own moral credibility when victims are compelled to violate international law in order to defend themselves.

\section{B. Barring the Use of Force Against Armed Attackers Between Their Unlawful Attacks}

Consider the implications of a strict interpretation of Article 51 for effective deterrence against a sequence of discrete attacks. On October 16, 1987,

\footnotetext{
136 See, e.g., Draft Code of Offenses against the Peace and Security of Mankind, Report of the International Law Commission, $6^{\text {th }}$ Session, [1954] II ILC Y.B. 140, 151 (Article 2(6)) [hereinafter Draft Code of Offenses against the Peace] (prohibiting "the toleration by the authorities of a State of organized activities calculated to carry out terrorist acts in another State"). If the host state is either unaware of the presence of the armed group or unable to control it, then the host state bears no responsibility for the attacks under international law.

137 See Mark A. Drumbl, Victimhood in My Neighborhood: Terrorist Crime, Taliban Guilt, and the Asymmetries of the International Legal Order, 81 N.C. L. REV. 1, 17-19 (2002).

138 See id. at 27 ("If the party responsible for an attack is not a state, a state actor, or agents sent by a state government, then the lawfulness of the use of armed force on a state where that party is believed to be is open to question.").
} 
the Kuwaiti tanker Sea Isle City, which had been re-flagged to the United States, was hit by an Iranian missile near a Kuwaiti harbor. Finding that Iranian oil platforms were being used as staging facilities for the attacks against shipping in the Gulf, three days later the U.S. attacked and destroyed two Iranian offshore oil production installations. A few months later, on April 14, 1988, a U.S. frigate struck an illegal mine laid by Iran in international waters near Bahrain. Five days later, the U.S. attacked and destroyed two oil platforms belonging to the National Iranian Oil Company. Prior to each attack, U.S. forces notified civilian personnel of the impending attack and gave them time to evacuate.

The illegal Iranian attacks could not be effectively prevented as they occurred. Missile strikes can come from anywhere at any time. Mines, almost by definition, do not permit an immediate response against the aggressor because the aggressor has laid the mine and long since departed. Where preventing an attack using immediate defensive force is impossible, the only means of preventing future attacks is to disable or deter the attackers after the attack is complete.

Several leading states understood the predicament of the United States and supported its actions. The French Government approved of the U.S. response, ${ }^{139}$ while the British Foreign Secretary, Sir Geoffrey Howe, "warned Iran against further attacks on shipping in the Gulf and hinted at action if a Britishflagged vessel were hit." 140 Howe went on to state that "[ $\mathrm{t}]$ here is no question of retaliation. It was action taken in exercise of its (Washington's) right of selfdefence. Any country is entitled to take action in self-defence." 141 In other words, the British agreed that defensive force need not be used in immediate response to an armed attack in order to constitute legitimate self-defense.

Yet, in its Oil Platforms decision, the ICJ found that the U.S. response violated international law, in part because its use of force was not designed to repel an ongoing armed attack. ${ }^{142}$ As Judge Simma wrote in a Separate Opinion,

\footnotetext{
139 Robert Fisk and Michael Binyon, Iran War Threat over US Attack: Crisis in the Gulf Escalates, THE Times (LONDON), Oct. 20, 1987, available at FACTIVA, Doc. T000000020051002djak00ask. 140 Andrew McEwen, Navy Could Follow US Policy of 'Self-Defence', THE Times (LONDON), Oct. 21, 1987, available at Factiva, Doc. T000000020051002djal00aln.

${ }^{141} I d$.

142 See Robert D. Sloane, The Cost of Conflation: Preserving the Dualism of Jus ad Bellum and Jus in Bello in the Contemporary Law of War, 34 YALE J. INT'L L. 47, 84 (2009) (arguing that according to the Oil Platforms decision "[a] defensive strike is only ad bellum necessary, in this view, if carried out, first, in immediate response to a particular attack and, second, against the attack's direct source. In contrast, the Court said, strategic strikes in self-defense carried out in an effort to deter future
} 
the United States was permitted only to engage in "defensive measures designed to eliminate the specific source of the threat or harm to affected ships in, and at the time of, the specific incidents." 143 However, had U.S. forces followed such restrictions on the use of force, they would have found themselves effectively powerless to respond in any meaningful way. Under the ICJ's interpretation of international law, once the Iranian units responsible for the attacks had laid their mines or launched their missiles and withdrawn, the U.S. was barred from striking those units at a time when they could have been reached. Here international law provides a legal shield for unlawful aggressors and thereby serves to encourage attacks and to make effective defense more difficult if not impossible.

Of course, the use of force in between attacks is seldom permitted in domestic criminal law. Typically victims can summon the police to intervene and prevent future attacks. However, when police assistance is not available, victims retain the right to use defensive force when immediately necessary. For example, the victim of a kidnaping who has been repeatedly assaulted by the kidnapper may use defensive force in between the assaults if the opportunity arises. ${ }^{144}$ In international law, no reliable enforcement authority exists to be summoned, and states are sometimes left with little choice but to respond to repeated attacks on their own.

The prohibition of force except during an armed attack is especially problematic when the source of the attack is a clandestine armed group whose attacks are deadly but episodic and whose identity and location may take time to determine. For example, on August 7, 1998, the Al Qaeda terrorist organization bombed the American embassies in Nairobi, Kenya, and Dar es Salaam, Tanzania, killing more than 300 civilians. On August 20, the United States launched missiles against an $\mathrm{Al}$ Qaeda training camp in Afghanistan and a suspected chemical weapons factory in Sudan.

Although the ICJ's interpretation of the UN Charter would seem to prohibit such uses of force, when one attack is over and another has yet to begin, the U.S. action was supported by a number of leading states, including Great

attacks of the same sort were per se unlawful. Once the initial attack ends, it reasoned, so too does the ad bellum necessity for self-defense.").

143 Oil Platforms (Iran v. U.S.), 2003 ICJ 161, 333 (Nov. 6) (separate opinion of Judge Simma) (emphasis added).

144 See 2 Paul Robinson, Griminal Law Defenses $§ 131(\mathrm{c})(2)$, at 79 (1984). 
Britain, Germany, Australia, and New Zealand. ${ }^{145}$ French Prime Minister Lionel Jospin insisted that " $[\mathrm{w}]$ herever terrorism is launched from, we must respond with a firm and decisive answer." ${ }^{46} \mathrm{Al}$ Qaeda had staged a prior attack on the United States - bombing the World Trade Center in 1993-but international law prohibited the United States from using force after that attack to degrade $\mathrm{Al}$ Qaeda's capabilities for their avowed next attack. One may wonder whether these legal constraints also discouraged the United States to launch more robust efforts to combat Al Qaeda prior to the attacks of September 11, 2001, and whether the protection the law offered $\mathrm{Al}$ Qaeda encouraged it in that and other attacks.

For all of these reasons, the prohibition of force except during an armed attack encourages unlawful aggression by advantaging aggressors at the expense of victims. Aggressors can discount the risk of attack by relying upon international law to shield the costs of the attack to them. The international law rule compounds the problem by increasing the tactical advantage of aggressors who launch hit-and-run attacks while depriving victims of the ability to select a time, place, and target that is most advantageous to them. Moreover, by forcing victims to break the law as the only means to protect themselves in a world without an effective international law enforcement mechanism, the law only undermines its own moral credibility and thereby loses the power of normative influence.

\section{Barring the Use of Force Except Against the Source of an Unlaweful Armed Attack}

The same reading of Article 51 that leads to restrictions on the use of force in between attacks also leads to restrictions on the use of force against targets other than "the specific source of the threat or harm ... in, and at the time of, the specific incidents." 147 Specifically, it seems that a victim state cannot use force against entities that played supporting roles in an earlier attack in order to prevent them from playing such supporting roles in a future attack. Thus, in the Oil Platforms case, the ICJ held that the U.S. was authorized to use force against the source of the Iranian missiles, which it could not find, or against the Iranian mine-layers, which it could not catch, but it was not authorized to use force against the oil

\footnotetext{
145 See Jules Lobel, The Use of Force to Respond to Terrorist Attacks: The Bombing of Sudan and Afghanistan, 24 YALEJ. INT'L L. 537, 538 (1999).

146 Edmund L. Andrews, After the Attacks: The Reaction, N.Y. Times, Aug. 22, 1998, at A6; see also id. ("Leaders from most other Western European nations, among them Britain, Spain and Austria, all characterized the American attacks as justifiable and appeared ready to believe Washington's assertions that the strikes were a response to overwhelming evidence it had amassed of planned terrorist attacks.").

147 See Oil Platforms, supra note 143, at 333 (emphasis added).
} 
platforms used to coordinate those two past attacks and that might be used to coordinate future attacks. ${ }^{148}$

Domestic criminal law rarely confronts situations in which defensive force is directed not at an attacker but instead at someone supporting the attack, presumably because it is seldom necessary or effective to use defensive force in this way. One could imagine a situation in which a victim might use defensive force against an accomplice who is about to hand a weapon to the attacker or reveal the victim's hiding place. But accomplices seldom make themselves liable to defensive force in these ways and are generally best dealt with through criminal prosecution after the fact. By contrast, military operations involve the close coordination of offensive and support activities, and often the most effective way to disrupt the former is to direct defensive force against the latter.

The limitations imposed by the ICJ on the use of defensive force against supporting entities are all the more remarkable because they seem to deviate from the well-accepted law that existed prior to the UN Charter. Recall that, during the Caroline incident, the colonial British did not respond directly against the rebels but instead destroyed a private vessel supplying the rebels with arms and provisions but not directly participating in the hostilities. The Caroline was destroyed at night when no armed attack was ongoing and when the ship was not being used to supply the guerillas. ${ }^{149}$ Yet for two centuries international lawyers have operated on the assumption that the permissibility of the attack on the Caroline turned on the criteria of immediacy, necessity, and proportionality and not on any categorical ban on attacking entities supporting but not engaging in aggression. An analogous situation existed in the Oil Platforms case. The United States responded to a sea mine and a missile attack not by targeting the source of the missile or mine, which it could not reach or identify, but rather by targeting oil platforms that were being used to plan and coordinate Iranian naval activities. Yet, that U.S. action was held illegal under an interpretation of international law that serves only to advantage unlawful aggressors, disadvantage victims, and undermine the moral credibility of international law as it compels victim states to break the law as the only effective means they have to defend themselves against future attacks.

${ }^{148} I d$.

149 See supra Part II.C. 


\section{Barring Deterrent Force}

While armed reprisals were once the main form of coercive enforcement of international law, today states are authorized to resort to force only to provide protection from ongoing attacks and not to deter future attacks. ${ }^{150}$ Indeed, "[f]ew propositions about international law have enjoyed more support than the proposition that, under the Charter of the United Nations, the use of force by way of reprisals is illegal" 151 Since the UN Charter permits the use of force only to repel an ongoing armed attack, ${ }^{152}$ armed reprisals are necessarily forbidden because by definition they respond to an armed attack that has already come to an end, ${ }^{153}$ while any future attack has not yet occurred. ${ }^{154}$ The prohibition against deterrent force raises serious problems for maintaining security and stability in the modern world of irregular warfare.

In April 1993, the U.S. government learned that the Iraqi government had assisted in the attempted assassination of former U.S. President George H.W. Bush. ${ }^{155}$ On June 26, 1993, U.S. missiles destroyed the Iraqi intelligence complex in downtown Baghdad. ${ }^{156}$ Although it seems difficult to consider the strike anything other than deterrent force that was illegal under the UN Charter, it is unclear what alternatives were open to the U.S., short of all-out war, to prevent

\footnotetext{
150 See General Assembly Resolution 2625 (XXV), Declaration on Principles of International Law Concerning Friendly Relations and Cooperation Among States in Accordance with the Charter of the United Nations (Oct. 24, 1970) ("States have a duty to refrain from acts of reprisal involving the use of force.").

151 Derek Bowett, Reprisals Involving Recourse to Armed Force, 66 AM. J. INT’L L. 1, 1 (1972). See also DinsteIN, supra note 17, at 198 (observing that "most writers deny that self-defence pursuant to Article 51 may ever embrace armed reprisals"); IAN BROWNLIE, INTERNATIONAL LAW AND THE USE OF FORCE BY STATES 281 (1963) (citing authorities).

152 See DinsteIn, supra note 17, at 192-93 (discussing the permissibility of on-the-spot reactions to small-scale armed attacks "by those under attack or present nearby").

153 See Bowett, supra note 151, at 3 (observing that "coming after the event and when the harm has already been inflicted, reprisals cannot be characterized as a means of protection").

154 See id. at 10 (observing that deterrent reprisal "takes on the character of . . 'preventive' war or acts of warfare") See also O'CONNELL, supra note 23, at 320 ("If a state experiences a single attack on its territory and has no evidence of future attacks, then it has no case for military force for the purpose of self-defense against attacks.") .

155 Alan D. Surchin, Terror and the Law: The Unilateral Use of Force and the Fune 1993 Bombing of Baghdad, 5 DukE J. COMP. \& INT’L L. 457, 464 (1995).

${ }^{156} \mathrm{Id}$. at 457. See also id. at 459 ("Though the Pentagon reported that the bombing was scheduled for the middle of the night so as to avoid civilian casualties, three missiles went off course and landed in a residential neighborhood in Baghdad. The official Iraqi news agency INA reported eight civilians killed.").
} 
further assassination attempts in the future. Unsurprisingly, "[o]nly China criticized the U.S. action, which most other states either supported or understood." 157

Or consider the terrorist bombing of the La Belle discotheque in West Berlin, on April 5, 1986, killing two U.S. servicemen and one civilian and injuring 50 servicemen and 180 civilians. Responsibility was eventually attributed to the Libyan government. Believing that non-forceful responses were unlikely to deter future attacks, and with no effective international law enforcement mechanism or effective defensive measure against such random attacks, the United States used armed force to deter future such attacks. Ten days after the bombings, U.S. planes attacked Libyan air defense networks, two airfields, two barracks, and a training camp. Approximately 40 people were killed. Soon thereafter, UN Secretary General Javier Perez Cuellar announced that the United States action violated international law and the UN General Assembly adopted a resolution condemning the United States for the attack by a vote of 79 to 28, with 33 abstentions. ${ }^{158}$ Yet it is unclear what alterative the U.S. had other than to simply suffer such attacks indefinitely.

Naturally, domestic criminal law does not permit victims of past attacks to pursue their attackers and retaliate against them. The responsibility to punish past crimes lies with the state alone and individuals may not take the law into their own hands. However, in the international system there is no centralized enforcement authority that reliably punishes past aggression. The prohibition of deterrent force therefore means that states are left to rely upon political pressure, economic boycotts, or other non-forceful counter-measures. While such alternative responses sometimes prove successful, they will almost always provide a less reliable and more temporally remote response to unlawful aggression than armed force, with a correspondingly weaker deterrent effect against future attacks. For example, after the bombings of Pan Am Flight 103 in 1988 and UTA Flight 772 in 1989, Libya resisted repeated Security Council Resolutions imposing economic sanctions and demanding only that Libya release those responsible for trial. Libya did not extradite the Pan Am suspects until 1999 and only agreed to

\footnotetext{
157 See FRANCK, supra note 12, at 94.

158 See William V. O'Brien, Reprisals, Deterrence and Self-Defense in Counterterror Operations, 30 VA.J. INT'L L. 421, 467 (1990). Apparently, "even states inclined to accept that Libya was systematically targeting US overseas personnel also thought the US aerial strike disproportionate to that threat." See FRANCK, supra note 12, at 90. While all responsive force must be limited by proportionality, it appears that international law prohibits even proportionate deterrent force.
} 
compensate the families of the victims in 2003. ${ }^{159}$ Moreover, states need not fear UN sanctions so long as they have the support of one or more permanent members of the Security Council. For example, Russia and China successfully prevented sanctions from being imposed on Syria for the assassination of former Lebanese Prime Minister Rafik Hariri in blatant violation of international law. ${ }^{160}$

The prohibition against deterrent force also has the perverse effect of forcing states to choose between ineffective avenues of redress or all-out war, with no intermediate legal option. ${ }^{161}$ For example, suppose that in the Oil Platforms case the United States responded to the Iranian attacks with exclusively non-forceful measures. Suppose that these measures failed and that Iran then responded by escalating its attacks on U.S. vessels. At some point, the United States would then have become justified in declaring war against Iran and the two nations would have entered a costly, bloody, and unnecessary conflict. Instead, the United States launched two limited strikes and (apparently) successfully deterred further aggression.

\section{E. Making Victims Into Outlaws and Condoning Force by Unlawful Aggressors}

Discouraging victims of unlawful aggression from defending themselves is just one of the unfortunate effects of current international law rules. As noted, the rules also promote aggression by giving unlawful aggressors special protections that translate into tactical advantages. They can pick the place and time when their attacks can do the most damage to victims with the least risk to themselves, then retreat behind the protections of current law until the next opportunity arises.

\footnotetext{
159 Background Note: Libya, U.S. DeP’T OF STATE (July 7, 2011), http://www.state.gov/r/pa/ei/bgn/5425.htm.

160 See Draft Code of Offenses against the Peace, supra note 136, art. 2(9) ("The intervention by the authorities of a State in the internal or external affairs of another State, by means of coercive measures of an economic or political character in order to force its will and thereby obtain advantages of any kind."). Colum Lynch \& Robin Wright, Security Council Split Over Resolution on Syria, WASH. POST, Oct. 25, 2005, at A13, available at http://www.washingtonpost.com/wpdyn/content/article/2005/10/24/AR2005102401070.html. Russia and China have also prevented sanctions from being imposed on Iran for refusing to suspend uranium enrichment in accordance with UN Resolutions and on Sudan, Myanmar, and Zimbabwe for widespread violations of human rights. See, e.g., Jeffrey A. Meyer, Second Thoughts on Secondary Sanctions, 30 U. PA. J. INT'L L. 905, 919-21 (2009).

161 See Dinstein, supra note 17, at 228.
} 
But the implications of international law's unjust rules are actually worse than this. International law not only gives unlawful aggressors a shield, but also a sword. When a victim responds to unlawful aggression with force that is necessary and proportionate but nevertheless barred under international law, that response makes the victim an unlawful aggressor under international law, against which the original aggressor now has a legal right to use armed force. Imagine the following scenario:

State $X$ wants to injure State $Y$. However, an attack by State $X$ would be unlawful under international law and $X$ wants to appear to be law-abiding and to give State $Y$ no legal basis to use defensive force. So State $X$ supports an armed group, which it hosts within its borders. The group stages armed attacks on State $Y$, then retreats to sanctuary in State $X$. International law prohibits State $Y$ from engaging the attackers while in their sanctuary in State $X$.

State $Y$ finally decides that it cannot afford to let the attacks continue because they are too destructive, and uses force against the armed group within State $X$. This is a violation of international law. International law treats State $Y$ as an unlawful aggressor and therefore gives State $X$ a right to use force in defense against State r.

Thanks to international law's improper limitations on responsive force, State $X$ can now launch the use of force that it originally contemplated, without violating international law.

The problem is not unique to situations like the one described above, but can arise under any of the improper limitations on responses to unlawful aggression that we have noted above. Any response to unlawful aggression, even one that is necessary and proportionate but that is nevertheless in violation of international law's unjust and unwise limitations, makes the victim state an outlaw against whom the aggressor state may lawfully use force. The result is not only grotesquely unjust, but also provides incentives that encourage and facilitate aggression, rather than deter aggression.

VII. Implications for the Interpretation and Reform of International Law

It is possible to avoid many of the difficulties described above in Part VI through creative reinterpretation of existing international law. What progress can 
be made along these lines is explored below in Section A. However, reinterpretation alone is not adequate to provide the certainty and specificity required to regulate the use of deterrent force. What is needed is substantive reform of existing international law. Section B offers specific proposals.

\section{A. Alternative Interpretations of Existing International Law Texts}

Consider each of the improper limitations on the use of force in response to unlawful aggression discussed in Part VI.

1. Permit Necessary and Proportionate Defensive Force Against States Supporting Unlawful Aggression by Armed Groups

As we have seen, the ICJ has held that the provision of arms, supplies, or sanctuary by one state to armed groups who in turn use illegal armed force against another state does not itself constitute an armed attack by the first state. Therefore, the ICJ reasons, the second state has no right to use defensive force against the first. ${ }^{162}$ However, even if we accept the premise, the conclusion simply does not follow. Recall that Article 51 of the UN Charter permits self-defense "if an armed attack occurs." However, once the right to self-defense is triggered by an armed attack, the UN Charter does not say that defensive force can only be directed at the source of the armed attack. The terms of Article 51 leave open the possibility that defensive force may be directed at those who aid and abet the source of the armed attack, or who supply the source of the armed attack with weapons and other essential operational resources. Such a reading would bring the power of decentralized deterrence by individual states to bear on those states that would, under the current interpretation, be free to finance, support, and encourage illegal attacks on others. Moreover, the provision of arms, support, or sanctuary to armed groups renders the provider at least partially responsible for any harm that comes or could come to a victim state as a result of the actions of those groups. Given the choice between shifting the costs of the unlawful aggression to a state partially responsible for it or leaving those costs to fall on the victim state, it seems fair to prefer the former option, and thus to allow victims states to use defensive force.

We propose that Article 51 be read to permit necessary and proportionate defensive force against either the source of an unlawful armed attack or a state that knowingly provides material support to the unlawful aggressor. Defensive

162 See supra Part VI.A. 
force should be permitted in cases when stopping the provision of arms, supplies, and support to an unlawful attacker is necessary to prevent or stop illegal attacks on the defending state and is proportionate to the threat of future attacks. Similarly, victim states should be permitted to use force against a sanctuary state if necessary to compel the sanctuary state to suppress unlawful armed groups operating on its territory (or to allow the victim state to do so) as well as proportionate to the threat posed by the armed group.

2. Permit the Use of Force Against Armed Attackers Between Their Unlawful Attacks

The ICJ has held that defensive force may only be used while an armed attack is still ongoing. Yet the wording of Article 51 suggests something quite different, namely that the right to self-defense is triggered "if an armed attack occurs" and continues to exist "until the Security Council has taken measures necessary to maintain international peace and security." 163 In other words, the right to self-defense does not end with the armed attack that triggers its application; rather, the right to self-defense ends only when the Security Council has taken measures to prevent future attacks. The terms of Article 51 therefore permit states to use defensive force while an armed attack is occurring or after an armed attack has occurred but before the Security Council takes appropriate action, so long as such defensive force is necessary to prevent future attacks and proportionate to the harm such future attacks would cause.

Therefore, we believe that the UN Charter can be fairly read to permit defensive force between the time an armed attack occurs and the time the threat of future attacks is eliminated either by defensive force on the part of the victim state or by action on the part of the Security Council. Force used after an initial armed attack that is necessary to prevent further armed attacks should be considered permissible. If an aggressor engages in a clear pattern of attacks and either declares that further attacks will follow or refuses to declare an end to such attacks then international law should permit the use of necessary, proportionate, and otherwise lawful defensive force. For example, if an armed group in State A launches repeated rocket attacks against State $\mathrm{B}$, and declares that it will continue such attacks unless State B accepts conditions it is not legally required to accept,

163 See UN Charter, art. 51. 
then State B should be permitted to use necessary, proportionate, and otherwise lawful defensive force against that armed group. ${ }^{164}$

3. Permit the Use of Force Against Military Objectives Used in Support of Unlawful Armed Attack

If we are correct that, under a plausible reading of the UN Charter, defensive force need not be directed against the source of an armed attack and that defensive force can be used in between attacks, then it naturally follows that defensive force may be used in between attacks to prevent further attacks that the targeted entity may enable or support but will not itself launch.

Needless to say, any military operation permitted by the rules governing the resort to force (jus ad bellum) is nonetheless constrained by the rules governing the conduct of hostilities (jus in bello), specifically the requirements of distinction, necessity, and proportionality. First, ordinarily civilian objects such as oil platforms may only be targeted if their use in armed attacks converts them into legitimate "military objectives . . . which by their nature, location, purpose or use make an effective contribution to military action and whose total or partial destruction, capture or neutralization, in the circumstances ruling at the time, offers a definite military advantage." 165 In other words, ordinarily civilian objects must actually be used to launch, enable, or support armed attacks for them to become liable to direct attack. Furthermore, "[w] hen a choice is possible between several military objectives for obtaining a similar military advantage, the objective to be selected shall be that the attack on which may be expected to cause the least danger to civilian lives and to civilian objects." 166 In other words, a victim state may not target an ordinarily civilian object that has been put to military use if it could prevent future attacks by selecting alternative targets the destruction of which will result in less loss of life or injury to civilians or damage to civilian property.

Finally, states must "refrain from deciding to launch any attack which may be expected to cause incidental loss of civilian life, injury to civilians, damage to

${ }^{164}$ Of course, if State B is legally required to accept the stated conditions or responds with unnecessary, disproportionate, or otherwise unlawful force then State B would no longer be acting within its rights.

165 Protocol Additional to the Geneva Conventions of 12 August 1949, and Relating to the Protection of Victims of International Armed Conflicts (Protocol I) art. 52(2), June 8, 1977, 1125 U.N.T.S. 3 (entered into force Dec. 7, 1978) (emphasis added) [hereinafter Protocol I]. ${ }^{166}$ Id. art. $57(3)$. 
civilian objects, or a combination thereof, which would be excessive in relation to the concrete and direct military advantage anticipated." 167 In other words, a victim state may only target an ordinarily civilian object that has been used in armed attacks if the future armed attacks it seeks to prevent are sufficiently grave to justify causing loss of life or injury to civilians or damage to civilian property.

These restrictions will almost always compel states to target core military targets such as troops, weapons, vehicles, equipment, and bases, rather than ordinarily civilian objects which have been put to military use. Generally, only in hit-and-run cases such as Oil Platforms will ordinarily civilian objects being put to military use become permissible targets, and even then every effort must be made to avoid or minimize harm to civilians. Subject to these restrictions, we believe that proportionate, limited force should be permitted against supporting entities in between attacks.

\section{Permit Necessary and Proportionate Deterrent Force}

As noted above, the majority of states and scholars believe that current international law forbids deterrent force. ${ }^{168}$ Yet we have also seen that the wording of Article 51 can be read to permit defensive force at a time between the occurrence of an unlawful armed attack and measures by the Security Council to prevent future attacks. No doubt members of the United Nations assume a duty under Articles 2(3) ${ }^{169}$ and 33(1) ${ }^{170}$ to resolve disputes peacefully, but given Article 51 this can only mean that states may not use force to prevent an unlawful attack if there is a reasonable likelihood that further unlawful attacks can in fact be avoided by peaceful means. It is also true that Article 39 vests in the Security Council the authority to "determine the existence of any threat to the peace, breach of the peace, or act of aggression and . . make recommendations, or decide what measures shall be taken ... to maintain or restore international peace and security." 171 But if a state that has already been the victim of an unlawful armed attack reasonably believes that it will suffer another armed attack before

${ }^{167} I d$. art. 57(2)(iii).

168 See supra Section VI.A.

169 See UN Charter, art. 2(3) ("All Members shall settle their international disputes by peaceful means in such a manner that international peace and security, and justice, are not endangered."). 170 See id. art. 33(1) ("The parties to any dispute, the continuance of which is likely to endanger the maintenance of international peace and security, shall, first of all, seek a solution by negotiation, enquiry, mediation, conciliation, arbitration, judicial settlement, resort to regional agencies or arrangements, or other peaceful means of their own choice.”).

171 See id. art. 39. 
the Security Council takes action, then arguably that state retains the right to use necessary and proportionate defensive force under Article 51.

Thus, the claimed prohibition on deterrent force derives not from the terms of the UN Charter, but rather from the narrow interpretation of the Charter that has been criticized above, as well as from separate international legal instruments such as General Assembly Resolution 2625. ${ }^{172}$ It follows that if states adopt the broader interpretation of Article 51 proposed above and enact new international legal instruments permitting necessary and proportionate deterrent force, then the unwise and unjust limitations on defensive force identified in Part VI can be avoided in the future.

We believe that deterrent strikes on military targets are best understood as a special case of anticipatory self-defense against future attacks, the permissibility of which we have advocated above. Indeed, deterrent force is probably the least problematic form of anticipatory self-defense, since it will generally be easier to show that force is necessary to prevent further attacks by a military force that has already committed an act of aggression than to show that force is necessary to prevent a first strike. Those who believe the principles of necessity and proportionality alone are insufficient to regulate anticipatory self-defense should consider adopting proportionate deterrent force as a compromise position.

We recognize that the use of deterrent force creates a risk of escalating conflicts. Indeed, "[ $\mathrm{t}]$ he degenerating effect of reprisals is probably the strongest argument against them." 173 However, just as we believe that self-defense against uses of illegal force that are limited in their "scale and effects" should be regulated by norms of necessity and proportionality rather than prohibited outright, so too do we believe that deterrent force should be regulated rather than prohibited. As Sloane observes, "[b]ecause force often proves insusceptible to prohibition, the law should focus equal or more attention on regulation."174 The precise framework for regulation is discussed in Part VII.B below.

As we have maintained throughout, the peaceful resolution of disputes must be pursued wherever possible and both unlawful aggression and disproportionate responses should be censured. But so long as the costs of deterrence are borne by members of an aggressing military force, it is legitimate

172 See supra note 140.

173 Bowett, supra note 151, at 16.

174 Cf. Sloane, supra note 142, at 107. 
for states to use deterrent force to prevent future attacks. Our position is not to require deterrent force, of course, but rather to allow a victim state to decide for itself whether deterrent force is necessary to prevent further unlawful aggression and is generally in its long-term security interests.

The foregoing endorsement of deterrent force may surprise some readers since both authors have elsewhere rejected deterrence as a distributive principle of criminal punishment on consequentialist and nonconsequentialist grounds. ${ }^{175}$ As discussed earlier, deterrence is often an ineffective distributive principle because ordinary criminals are often ignorant of both legal rules and prescribed punishments, discount the probability that they will actually be punished, or fail to rationally calculate their self-interest. In international affairs, by contrast, deterrent force can send a fairly clear deterrent signal (namely, "don't attack us again or we will retaliate again") to unlawful aggressors who are at least capable of rationally managing their self-interest.

Similarly, from a nonconsequentialist perspective, it is morally illegitimate to punish an innocent criminal defendant in order to deter others; this is the famous 'scapegoating' objection to general deterrence. The scapegoating objection works because, except in cases of strict or absolute liability, the only way to become liable to punishment is to morally deserve punishment. By contrast, being subject to the use of necessary defensive force does not depend on moral desert: defensive force may be used against an "innocent aggressor" who is insane, under duress, or acting on the basis of a reasonable mistake of fact. ${ }^{176}$ Similarly, combatants are properly subject to defensive force even if they are neither deserving of nor liable to punishment. ${ }^{177}$ There is therefore no contradiction between rejecting deterrence as distributive principle of criminal punishment and defending deterrent force as a form of legitimate self-defense.

\footnotetext{
175 See, e.g., Adil Ahmad Haque, Legitimacy as Strategy, in Criminal Law Conversations 57-59 (Paul H. Robinson et al. eds., 2009); Paul H. Robinson, The Difficulties of Deterrence as a Distributive Principle, in Criminal Law Conversations 105-16 (Paul H. Robinson et al. eds., 2009).

176 See, e.g., George P. Fletcher \& Luis E. Chiesa, Self-Defense and the Psychotic Aggressor, in CRIMINAL LAW CONVERSATIONS, supra note 175, at 365-72.

177 The permissibility of using defensive force against particular soldiers does not depend on their individual contributions to acts of aggression but rather on their status as combatants. Cf. WALZER, supra note 96, at 138 (observing that "once war has begun, soldiers are subject to attack at any time"). For this reason, we believe that deterrent force may target either the military units involved in prior acts of aggression or different military units of the same armed force.
} 
We fully accept the legal prohibition on deterrent force against a civilian population. ${ }^{178}$ Intentionally killing or injuring civilians as a means of compelling a government or armed group to change its behavior is morally impermissible, and indeed constitutes the moral wrong of terrorism. Civilians who do not take direct part in hostilities have done nothing to morally deserve to be harmed or to become liable to defensive force. Intentionally harming civilians in order to deter their government or armed groups from launching armed attacks is therefore akin to intentionally punishing an innocent scapegoat in order to deter crime, which even most consequentialists concede should not be legally permissible. Indeed, any general or specific deterrence that might be achieved by permitting such conduct would be outweighed by the damage its permissibility would do to the moral credibility of international law. Finally, it is possible that deterrent force against civilians is more likely to result in escalation than deterrence, since such force seems likely to trigger a vengeful emotional response rather than a cool deliberative weighing of costs and benefits.

The permissibility of deterrent force against non-military government facilities and government-owned commercial property presents a closer question. Suppose for a moment that the Iranian oil platforms were no longer being used to coordinate or launch attacks against the United States and its allies, but that the United States had good reason to believe that destroying those platforms would nonetheless deter future Iranian attacks. Indeed, it appears that U.S. forces targeted at least one oil platform that had not been used in a prior attack as what the ICJ condemned as "a target of opportunity." 179 Even if U.S. forces ensured that civilians were evacuated from the platforms, international law would forbid their destruction since the platforms would not constitute legitimate military objectives but rather civilian objects that are not liable to direct attack. ${ }^{180}$ Similarly, if the United States had good reason to believe that destroying oil fields

\footnotetext{
178 See Protocol I, supra note 165, art. 51(6) ("Attacks against the civilian population or civilians by way of reprisals are prohibited.").

179 See Sloane, supra note 142, ๆ 76.

180 See Protocol I, supra note 165, art. 52(1) ("Civilian objects shall not be the object of attack or of reprisals.") \& 52(2) (“[M]ilitary objectives are limited to those objects which by their nature, location, purpose or use make an effective contribution to military action and whose total or partial destruction, capture or neutralization, in the circumstances ruling at the time, offers a definite military advantage."). In the scenario discussed, the platforms no longer make an effective contribution to military action and it is therefore irrelevant that their destruction offers a definite military advantage (namely deterrence).
} 
owned by the Iranian government would deter future Iranian attacks, U.S. forces would nevertheless be prohibited from targeting those oil fields. ${ }^{181}$

The deterrent effect of using force against such non-military government targets may be significant, but before altering the jus in bello principle of distinction to permit direct attacks against such facilities, one should compare the range of permissible uses of such a right against the range of impermissible abuses of such a right, as well as the difficulty of enforcing the boundary between the two. First, deterrent force against non-military government targets will generally violate in bello necessity since a similar deterrent effect can typically be achieved by selecting a different target the destruction of which would result in less loss of life or injury to civilians as well as less damage to civilian property. Second, deterrent force against such targets will generally violate in bello proportionality since the anticipated loss of life or injury to civilians or damage to civilian property must be weighed against the "concrete and direct overall military advantage" sought; the deterrence of a future attack by destroying an object that will not be used to launch or facilitate the attack, may be too remote and indirect an advantage to justify loss of life or injury to civilians not taking direct part in hostilities. Only in rare cases, in which loss of life and injury to civilians can be avoided entirely, could these jus in bello principles be satisfied. By contrast, making non-military government facilities into legitimate targets could open the door to attacks on any government facility from ministries to embassies, airports to police departments, welfare agencies to courthouses.

Certainly, it is not plausible to think that every government employee assumes the risk that he or she will be threatened, injured, or killed in retaliation for an armed attack launched by his or her government. Moreover, the permissibility of attacking such facilities would apply not only to isolated acts of self-defense, which could be thoroughly investigated and evaluated for their compliance with both ad bellum and in bello principles of necessity and proportionality, but also to the conduct of war itself, in which such fact-intensive inquiries into possible abuses are often impossible. Given such a marginal benefit to changing the laws of war, compared with a significant risk of abuse, it seems desirable to retain the current blanket prohibition on deterrent force against nonmilitary objectives.

\footnotetext{
181 The use of force against oil platforms and oil fields may also implicate the duty to take care to protect the natural environment from "widespread, long-term and severe damage." Protocol I, supra note 165, art. 55(1).
} 


\section{B. Reform Proposals}

For the reasons above, we believe that Article 51 can be fairly interpreted to permit deterrent force, defensive force in between attacks, and defensive force against states and other entities that support acts of aggression. Even a fair reinterpretation of the UN Charter, however, cannot provide the clarity and specificity necessary to regulate the use of such defensive force. We therefore propose several reforms of international law.

First, we would supplement the language proposed in Section IV.B for an international law rule governing the use of force to be adopted through a UN Security Council resolution or international convention, with the italicized language as follows:

Use of Force in Self-Defense

(1) Defensive Force. A state may use force to prevent unlawful aggression, before or during its occurrence, provided that such force is:

(a) immediately necessary to prevent such unlawful aggression, and

(b) proportionate to the harm that such unlawful aggression would cause if not prevented.

(2) "Unlawful Aggression." For the purposes of this rule, "unlawful aggression" means the threat or use of armed force by a state or armed group that infringes the territorial integrity or political independence of a state and that involves substantial loss of life, physical injury, or damage to property.

(3) Deterrent Force. A state may use force in response to a prior act of unlawful aggression, provided that such force is:

(a) necessary to deter further acts of unlaweful aggression,

(b) proportionate to the unlaweful aggression, and

(c) used before the Security Council takes measures that will maintain international peace and security.

(4) Permissible Targets. The use of force authorized under this section may be directed at the state or armed group that is or will be the source of the unlawful armed aggression, at a state or armed group that provides military equipment, training, financial support, sanctuary, or other resources to such aggressor, or at a state that allows the use of its territory knowing that the recipient will undertake unlawful aggression.

(5) Report. Force used under this section shall be immediately reported 


\section{to the Security Council and this report shall include a clear statement of the evidence that unlawful aggression has occurred or will occur unless such force is used.}

We recognize that the authorization of deterrent force under section (3) creates a risk of escalation. However, we believe that the risk of escalation can be controlled without resorting to wholesale prohibition of deterrent force. It will be in each victim state's interest to realistically evaluate the likelihood of escalation. A state may have a right to use deterrent force under section (3), yet calculate that their interests are better served by not exercising that right. The point is, however, that they ought to have that option if such force is necessary to prevent future unlawful aggression.

Importantly, international law permits the use of "wartime" or "belligerent" force during armed conflict in order to deter repeated violations of the Law of International Armed Conflict (LOIAG). For example, if States $A$ and $B$ are at war with one another and during that war State $A$ uses illegal weapons against soldiers of State $B$, then international law permits State $B$ to use the same or similar illegal weapons against soldiers of State $A$. However, the LOIAC also imposes strict requirements on states seeking to engage in belligerent reprisals. The Red Cross articulates five such conditions:

(i) Purpose of reprisals. Reprisals may only be taken in reaction to a prior serious violation of international humanitarian law, and only for the purpose of inducing the adversary to comply with the law. . .

(ii) Measure of last resort. Reprisals may only be carried out as a measure of last resort, when no other lawful measures are available to induce the adversary to respect the law. ...

(iii) Proportionality. Reprisal action must be proportionate to the violation it aims to stop. ...

(iv) Decision at the highest level of government. The decision to resort to reprisals must be taken at the highest level of government. ...

(v) Termination. Reprisal action must cease as soon as the adversary complies with the law. ${ }^{182}$

\footnotetext{
182 JeAn-Marie Henckaerts \& LOUise Doswald-BeGK, Gustomary International HumanitARIAN LAW 515-18 (2005). The Red Cross asserts that "[i]n the course of the many armed conflicts that have marked the past two decades, belligerent reprisals have not been resorted
} 
Yoram Dinstein, a leading IHL scholar, identifies five overlapping conditions:

(i) Protests or other attempts to secure compliance of the enemy with LOIAC must be taken first (unless their fruitlessness 'is apparent from the outset').

(ii) A warning must generally be issued before resort to belligerent reprisals.

(iii) Belligerent reprisals must always be proportionate to the original violation of LOIAC.

(iv) The decision to launch belligerent reprisals cannot be taken by an individual combatant, and must be left to a higher authority.

(v) Once the enemy desists from its breach of LOIAC, belligerent reprisals must be terminated. ${ }^{183}$

Dinstein's first and second conditions are corollaries of the requirement that reprisals be used as a last resort, while the deterrent purpose of reprisals is assumed and only the constraints on that purpose examined. In short, then, belligerent reprisals should be necessary and proportionate responses to illegal attacks and should be designed to deter future illegal attacks; they should be public and follow warnings to enhance deterrence and accountability; and they should be authorized by politically accountable leaders who can best weigh the risk of escalation against the risk of future attack. These guidelines are designed to guide the use of deterrent force in the conduct of hostilities. They seem equally capable of guiding the use of deterrent force in response to unlawful aggression. Moreover, these restrictions on belligerent reprisals have been widely adopted by leading states as legitimate constraints on their conduct of hostilities. ${ }^{184}$ Finally, it

to ... [except during] the Iran-Iraq War, where such measures were severely criticised by the UN Security Council and UN Secretary-General." Id. at 513. The Red Cross then opines that "[t] he reticence of States to resort to reprisals can be explained by the fact that they are ineffective as a means of enforcement, in particular because reprisals risk leading to an escalation of violations." $I d$. at 514 . As we discuss in the body of this section, the risk of escalation should give any state pause before resorting to reprisals. However, we believe that states should have the right to weigh the risk of escalation against the risks involved in other available alternatives.

183 Yoram Dinstein, The CONDUGt Of Hostilities Under The Law Of INTERnATIONAL ARMed CONFLict 221 (2004). Cf. Richard A. Falk, The Beirut Raid and the International Law of Retaliation, 63 AM. J. INT'L L. 415, 441-42 (1969) (proposing similar criteria for reasonable reprisals in response to acts of aggression).

184 See, e.g., Air Force Pamphlet 36-2241, Section 6.9.2., at 114, available at http://www.epublishing.af.mil/shared/media/epubs/afpam36-2241.pdf. 
is important to note that the use of reprisals against civilians and civilian objects is and should remain unlawful. ${ }^{185}$

We propose similar restrictions on the use of the deterrent force authorized under section (3) above. We would add to section (3) an additional subsection, (d), as follows:

(d) Special Restrictions on Use of Deterrent Force

(i) Non-Force Alternative Preferred. Before undertaking the use of deterrent force, a state must enter a protest or otherwise attempt to secure a credible assurance that the unlaweful aggression will not be repeated, unless the fruitlessness of such an appeal is apparent from the outset.

(ii) Acknowledgment. Before or immediately after undertaking the use of deterrent force, a statement must be publicly issued, acknowledging that deterrent force will be or was used and identifying the act of unlawful aggression to which it is a response.

(iii) Proportionality. The use of deterrent force must be proportionate to the act of unlawful aggression to which it responds.

(iv) Decision by Higher Authority. The decision to use deterrent force cannot be taken by an individual combatant, and must be left to a higher authority.

(v) Termination Following Assurance. Once the unlawful aggressor provides a credible assurance that the aggression will not be repeated, use of deterrent force must be terminated.

Our proposal uses the phrase "deterrent force" rather than the more traditional phrase "deterrent reprisal" because the term "reprisal" has as part of its common meaning the infliction of suffering as punishment for a past harm that is at least as harmful as the earlier injury. ${ }^{186}$ Our requirement, in contrast, does not necessarily authorize force that would cause the extent of harm caused by the initial aggressor. ${ }^{187}$ The use of force authorized here is only that amount necessary

185 See Protocol I, supra note 165, arts. 51(6) ("Attacks against the civilian population or civilians by way of reprisals are prohibited.") \& 52(1) ("Civilian objects shall not be the object of attack or of reprisals.").

186 See, e.g., The American Heritage Dictionary, Office Edition 585 (1983) (defining "reprisal" as "Retaliation for an injury with the intent of inflicting at least as much injury in return").

187 We find the traditional phrase "deterrent reprisal" misleading or at least dangerously ambiguous on this point and suggest that it be avoided whenever possible. 
to deter a future attack. If that can be done by causing less harm than the harm caused by the initial aggressor, then no more than that lesser amount is authorized. ${ }^{188}$

Notice that the use of deterrent force, under section (3), must be proportionate to the act of unlawful aggression to which it responds. By contrast, defensive force intended to prevent unlawful aggression by destroying the capacity of the opposing party to engage in further unlawful aggression, under section (1), need only be proportionate to the harm that such further unlawful aggression would cause if not prevented. In other words, the use of deterrent force is limited by a backward-looking conception of proportionality, while use of defensive force is limited by a forward-looking conception of proportionality. This dichotomy is in keeping with the criminal law principles that, while we may not ethically deter crime by punishing an individual offender more than he or she deserves for his or her past offenses, we may prevent an aggressor from committing a crime by using force proportionate to that which the aggressor intends to use against us. However, the primary reason to require that deterrent force be proportionate to past aggression, rather than to anticipated future aggression, is to prevent escalation. The use of force can cause fear or anger, and may deter or incite. For that reason, deterrent force should be limited in scale and gravity to the scale and gravity of the unlawful attacks to which they respond.

VIII. The Aggression Resolution: Giving Teeth to the Injustices of Current Law

The Assembly of States Parties to the International Criminal Court is currently developing an amendment to the Rome Statute (the treaty that established the ICG and identifies the crimes that it may prosecute and punish) that will define a crime of aggression for which political and military leaders may be held individually criminally liable. This amendment could do much to move the law toward clear and sensible rules governing the use of force, and we applaud the effort. The previous parts have shown how the improper limitations that international law places on the use of defensive force undermine its own moral credibility and fail to harness the power of decentralized deterrence against unlawful aggression. We have shown how reinterpretations and reforms of current law could avoid these problems, empowering victims and discouraging aggression. It is true that reform of international law rules is often difficult to achieve, and some readers may think it unrealistic to expect any serious reform in the

188 This may occur when the original attacker is weaker or more vulnerable than the victim, as seems to increasingly be the case in the contemporary era of asymmetrical conflicts. 
foreseeable future. However, the amendment of the Rome Statute provides an important opportunity to begin the needed reforms.

Tragically, the amendment process has moved in the wrong direction. Rather than taking this unique opportunity to fix the flaws in current law, the current Aggression Resolution enshrines international law's current flawed rules. Worse, if adopted as a formal amendment, it would for the first time impose individual criminal liability on leaders who authorize force, even proportional force necessary to defend against unlawful aggression, in violation of those flawed rules. If the current Aggression Resolution is adopted, leaders will be criminally liable for authorizing rescue operations like the one at Entebbe, military operations against armed groups like the PKK, preventive strikes like the sinking of the French fleet at Mers el-Kebir, defensive force used in between attacks and not against the specific source of the attacks as in the Caroline incident, or armed reprisals like those used by the United States against Libya. Yet criminal liability in any of these cases would seem absurd. ${ }^{189}$ A regime of personal criminal liability for leaders who authorized such conduct, as is now proposed, serves only to further advantage unlawful aggressors and disadvantage their victims, promoting greater injustice and further undermining deterrence of unlawful aggression.

In the past, states faced with the choice between protecting themselves from unlawful aggression or obeying flawed international law rules could simply ignore the flawed rules and cite the justice and necessity of their actions to avoid political or diplomatic criticism. Such normalization of law-breaking is detrimental to the law's long-term moral credibility but at least it allows states to deal with the immediate threat of unlawful aggression. Under the Aggression Resolution, however, a state cannot defend itself against unlawful aggression without putting the leaders of the state in danger of individual criminal liability before the ICG. A leader who authorizes the use of necessary and proportionate defensive force could risk being branded a criminal and made subject to arrest, prosecution, and punishment. Worse still, when faced with the risk of individual criminal liability, some leaders may be tempted to put their personal interests ahead of the interests of their people and forgo the use of force needed for effective defense.

189 See supra note 24 and accompanying text; see supra notes 47-48 and accompanying text; see supra note 56 and accompanying text; see supra Part II.B; see supra note 158 and accompanying text. 


\section{A. How the Aggression Resolution Punishes Victims}

The problem arises because the Aggression Resolution, in its current form, incorporates the flawed UN Charter framework described above into the definition of the crime of aggression. The pertinent part of the Aggression Resolution reads:

1. For the purpose of this Statute, "crime of aggression" means the planning, preparation, initiation or execution, by a person in a position effectively to exercise control over or to direct the political or military action of a State, of an act of aggression which, by its character, gravity and scale, constitutes a manifest violation of the Charter of the United Nations.

2. For the purpose of paragraph 1, "act of aggression" means the use of armed force by a State against the sovereignty, territorial integrity or political independence of another State, or in any other manner inconsistent with the Charter of the United Nations. ${ }^{190}$

In plain terms, the Aggression Resolution criminalizes the use of armed force by one state against another state in "manifest violation" of the UN Charter. Thus, any use of defensive force not authorized by Article 51 of the UN Charter constitutes the "crime of aggression," even if it is proportionate and necessary to prevent unlawful aggression. As we have seen, Article 51 has been interpreted to deny a right to use defensive force: against acts of unlawful aggression that do not rise to the level of an "armed attack"; by armed groups operating from the territory of another state; to prevent an imminent armed attack; to prevent a planned attack that is not yet imminent; to prevent a state from providing support or sanctuary to armed groups; in between armed attacks; against targets other than the direct source of an armed attack; and to deter future armed attacks. ${ }^{191}$ Unless current law is changed to clearly reject these limitations on the use of force against unlawful aggression, the Aggression Resolution would impose personal criminal liability on leaders who authorize the use of defensive force in "manifest violation" of these illegitimate limitations. ${ }^{192}$

190 Aggression Resolution, supra note 2, at 5, Annex I, art. 8 bis (1)-(2).

191 See supra Parts II.A-C at 150-62; see also IV.A-B at 173-83.

192 Significantly, commentary produced by the Working Group on the Crime of Aggression suggests that to satisfy the elements of the crime of aggression a defendant must be aware of "the existence or absence of a prior or imminent attack by another State." See Non-paper by the 
The bleak scenario described above is not inevitable. As we have argued in Parts IV and VII, the text of the UN Charter can be fairly interpreted to avoid many (though not all) of the unjust limitations currently placed on defensive force. ${ }^{193}$ Should the ICC adopt the alternative interpretations of the UN Charter that we have proposed, it would thereby avoid most of the injustices of current international law. However, it is unlikely that the ICG will disregard the past decisions of the ICJ, no matter how flawed they now appear. Precedent in international law is so sparse that it would be surprising for the ICC to reject what little exists. Moreover, for years after the adoption of the Aggression Resolution, leaders of victim states will not know which uses of defensive force will result in their personal criminal liability. Leaders of victim states who order the use of defensive force will do so at their peril, not knowing which reading of Article 51 the ICG will adopt ex post facto. This inability to predict the legal consequences of national security decisions is almost as harmful to responsible decision-making as the knowledge that certain decisions will result in criminal liability.

\section{B. How the Aggression Resolution Fails to Deter Aggressors}

The previous section describes how the Aggression Resolution punishes victim states for using necessary and proportionate defensive force that nevertheless is not authorized under Article 51. Such undeserved punishment might be tolerable if the adoption of the Aggression Resolution would itself deter those acts of aggression against which Article 51 forbids victim states from using defensive force. If the ICG would effectively provide the centralized coercive enforcement that international law currently lacks, then there might be little need

Chairman on the Elements of Crimes, 28 May 2009, at 6, 20, available at http://www2.icccpi.int/iccdocs/asp_docs/SWGCA/Non-paper-Elements-of-the-CoA-28May2009-ENG.pdf. This is a welcome development, but we would urge that either the absence of an imminent attack be made an explicit element of the crime of aggression or the existence of an imminent attack be made an explicit element of an affirmative defense to the crime of aggression. Additionally, it could be argued that, under the Aggression Resolution, only a use of force that rises to the level of an armed attack under Article 51 possesses the "gravity and scale" necessary to constitute a "manifest violation" of the UN Charter. On such a reading, neither a limited act of aggression falling below the armed attack threshold nor a proportionate (and therefore equally limited) defensive response would constitute the crime of aggression. It follows that the Aggression Resolution would not unfairly punish victims but would instead confer impunity on aggressors. As we argue below, the correct position should be to condemn and punish deadly and destructive acts of aggression while empowering victims to use proportionate defensive force.

193 The unjust limitations that seem unavoidable under any fair reading of the UN Charter are those regarding imminent and non-imminent attacks. See Part IV.A.3-4 supra at 176-82. 
for states to use defensive force, and hence no problem if victim states are denied a right to effectively defend themselves. However, it seems clear that the ICG will not effectively deter unlawful aggression. State actors whose conduct satisfies the proposed elements of the crime of aggression may avoid prosecution by the ICG simply by not signing the Rome Statute, by signing the Rome Statute but declining to accept the Court's jurisdiction over aggression, or by currying favor with permanent members of the UN Security Council who can individually block referrals to the ICG or collectively suspend prosecutions indefinitely. ${ }^{194}$

Moreover, even if the ICG had the power to effectively deter unlawful aggression, the Aggression Resolution, in its current form, does not in fact criminalize many of the forms of unlawful aggression that we have discussed in the previous sections. First, the Aggression Resolution defines the crime of aggression to include only those uses of armed force whose "character, gravity and scale" constitute a "manifest violation" of the UN Charter. ${ }^{195}$ Thus, uses of armed force of limited gravity and scale are prohibited under Article 2(4) of the UN Charter but are not punishable under the Aggression Resolution. Second, consistent with current international law, the crime of aggression can only be committed by "a State," not by an armed group acting on its own. ${ }^{196}$ Third, the Aggression Resolution includes within the crime of aggression only sending an armed group to complete specific operations or substantial involvement in specific uses of armed force. ${ }^{197}$ The Aggression Resolution does not criminalize providing financial, military, or logistical support for a group that is organizationally independent from the state, even though international law prohibits any "encouragement" of armed groups. ${ }^{198}$ Fourth, while the proposed definition seems to impose criminal liability for the "planning, preparation, initiation or execution . . . of an act of aggression," "199 the proposed elements of the crime of aggression require that " $[\mathrm{t}]$ he act of aggression . . . was committed." 200 In other words, the planning or preparation of an illegal use of armed force does not constitute an

\footnotetext{
194 See Part V.A. supra at 183-84.

195 See Aggression Resolution, supra note 2, at 5, Annex I, art. 8 bis (1).

196 Id. Annex I, art. 8 bis (1) \& (2).

197 See Aggression Resolution, supra note 2, Annex I, art. 8 bis (2)(g). See also Nicaragua, supra note 16, at 346 (Schwebel, J., dissenting) (stating that the General Assembly Resolution from which the wording of the Aggression Resolution to the Rome Statute is substantially derived classifies "as an act of aggression a State's 'substantial involvement' in the sending of armed bands" into the territory of another state).

198 See Draft Code of Offenses against the Peace, supra note 136, arts. 2(4), 2(5), \& 2(6).

199 Aggression Resolution, supra note 2, Annex I, art. 8 bis (1).

200 Aggression Resolution, supra note 2, Annex II, art. 8 bis, Element 3.
} 
international crime unless that use of armed force in fact occurs. Moreover, the Rome Statute does not contain an inchoate crime of conspiracy and therefore does not impose criminal liability until an aggressor moves beyond planning or preparing and actually commences the execution of an act of aggression. This is so despite the fact that conspiracy to commit aggression was a crime under the Nuremberg Charter ${ }^{201}$ and is itself a violation of international law. ${ }^{202}$

In all such cases, states that are victimized by aggression that the international system cannot or will not punish are forced to choose between doing nothing, leaving the attacks unpunished and their attackers undeterred from further attacks, or resorting to uses of force not authorized by international law. If they elect to respond with force, then they will be the ones branded as aggressors and their leaders may be held criminally liable, while the true aggressors can escape without punishment and without the stigma of criminality.

\section{Guidelines for Reform}

To avoid punishing victim states for legitimate uses of defensive force, we urge the Assembly of States Parties to revise the Aggression Resolution to explicitly adopt the reinterpretations of Article 51 proposed in this Article. The Aggression Resolution should not leave it up to the ICG to interpret Article 51 during the course of future adjudication. As discussed above, ICG adjudication will likely reproduce the same unjust limitations on defensive force that currently exist. Moreover, states will not know what interpretation of Article 51 the ICG will adopt in future cases and this legal unpredictability is itself both unfair and unwise.

\footnotetext{
201 See Charter of the International Military Tribunal, Annexed to London Agreement for the Establishment of an International Military Tribunal art. 6(a), 8 Aug., 1945, 59 Stat. 544, 82 U.N.T.S. 279 (listing among Crimes Against Peace "participation in a common plan or conspiracy for the accomplishment of" a war of aggression). It is true that the Rome Statute imposes criminal liability on a person who "[a]ttempts to commit . . . a crime by taking action that commences its execution by means of a substantial step." See Rome Statute, supra note 118, art. 25(3)(f). It follows that a state official may be held criminally liable for attempted aggression if the intended act of aggression is interrupted while still in its early stages.

202 See Draft Code of Offenses against the Peace, supra note 136, art. 2(3) (prohibiting “ $[\mathrm{t}] \mathrm{he}$ preparation by the authorities of a State of the employment of armed force against another State for any purpose other than national or collective self-defence or in pursuance of a decision or recommendation of a competent organ of the United Nations"); see also id. art. 2(13)(i) (prohibiting "[c]onspiracy to commit any of the offences defined in the preceding paragraphs of this article").
} 
Instead, the Aggression Resolution should explicitly permit states to use necessary and proportionate defensive force against deadly or destructive uses of armed force by states or non-state actors whether these are ongoing, imminent, or planned but not yet imminent. Defensive force should also be explicitly permitted against supporting states and targets other than the direct source of an attack. Finally, defensive force should be explicitly permitted in between attacks, including in the form of deterrent force, until the Security Council takes measures necessary to maintain international peace and security.

Importantly, we believe that the Aggression Resolution should place the burden on defendants to prove that their belief that defensive force was necessary to prevent an imminent or planned attack was not only sincere but also reasonable and based on clear and convincing evidence. This requirement will help ensure that states do not abuse the broader right of self-defense that we advocate. The best way to prevent states from masking aggression behind fraudulent claims of anticipatory self-defense is not to deny the right of anticipatory self-defense to all states, aggressors and victims alike, but rather to force leaders to produce the evidence on the basis of which they concluded that defensive force was necessary and to subject that evidence to public scrutiny.

Finally, the Aggression Resolution should be revised to better utilize what little deterrent capacity the ICG possesses. First, the offense definition of aggression should criminalize all uses of armed force that may result in the loss of territory or human life, thereby deterring uses of armed force that are limited in their "gravity and scale." Second, the offense definition should criminalize the use of armed force by armed groups, thereby deterring both the armed groups themselves as well as state leaders who aid or abet those armed groups and who may therefore be held criminally liable as accomplices. ${ }^{203}$ Third, conspiracy to commit aggression should be included as an inchoate offense, in keeping with the Nuremberg precedent, ${ }^{204}$ which may be used to punish leaders who plan or prepare acts of aggression that do not occur, including acts of aggression prevented by the anticipatory defensive force of victim states.

\footnotetext{
203 See Rome Statute, supra note 118, art. 25(3)(c) ("In accordance with this Statute, a person shall be criminally responsible and liable for punishment for a crime within the jurisdiction of the Court if that person: ... [f] or the purpose of facilitating the commission of such a crime, aids, abets or otherwise assists in its commission or its attempted commission, including providing the means for its commission.").

204 See supra note 187 and accompanying text.
} 


\section{Conclusion}

As the previous parts have shown, the improper limitations that international law currently imposes on responses to unlawful aggression have the overall effect of advantaging aggressors and disadvantaging victims, an effect that can only hurt the cause of justice and stability. While it seems unrealistic to think that Article 51, or any other aspect of the UN Charter, will soon be amended, we urge the Assembly of States Parties to the International Criminal Court to revise its Aggression Resolution before its members can vote to formally amend the Rome Statute beginning in $2017 .{ }^{205}$

To be clear about our proposals: Nothing requires a victim state to do anything in response to unlawful aggression. States may rightfully worry that a response will yield more risk than reward. But international law ought to at least allow victim states to determine for themselves whether responding to unlawful aggression with force is in their long-term self-interest. Current international law, and especially the proposed definition of the crime of aggression, seriously limits a victim state's options.

In a larger perspective, the advantaging of unlawful aggressors hurts all states as it undermines international stability. It is not hard to imagine that the current limitations on responses to unlawful aggression have contributed to the unfortunate frequency of aggression in today's world. If current international law did not impose such costs - of having to break the law to defend against unlawful aggression - one can imagine instances where some past aggressors might have hesitated and some past victims might have responded, helping to avoid future aggression. ${ }^{206}$

More than anything, international law's unjust limitations on the use of defensive force miss an opportunity to make international law a more effective force for justice and peace. Every time international law condemns a leader for

\footnotetext{
${ }^{205}$ Such reforms would particularly benefit states that accept the legitimacy of international law despite its flaws. Currently, aggressors are able to use the unjust limitations of international law to their strategic advantage, using unlawful armed force in ways that do not trigger the right of selfdefense under Article 51. Meanwhile, victim states that accept the legitimacy of international law will either obey international law to their own detriment or be compelled to violate international law and suffer that additional moral and reputational cost to themselves. By contrast, states that reject the legitimacy of international law, and that would not hesitate to violate international law to protect themselves, currently present more dangerous targets for an aggressor. 206 See supra note 52 and accompanying text (discussing the 1973 Arab-Israeli War).
} 
ordering the use of necessary defensive force-U.S. President Barack Obama, for instance, for authorizing missile strikes on Al Qaeda camps in Pakistan - it reduces its ability to effectively condemn leaders who violate both international law and principles of justice - Sudanese President Omar Al-Bashir, for instance, for crimes against humanity against the people of Darfur.

If this were a different world - one with an effective centralized law enforcement authority, something akin to modern domestic criminal law-one might be able to support some (though not all) of the law's limitations on responses to aggression, specifically, those limitations discussed in Part VI. But that is not the world in which we live, nor the world that we are likely to see in our lifetimes, the noble efforts of the International Criminal Court notwithstanding. As discussed previously, the Court cannot effectively enforce international law. ${ }^{207}$ Moreover, if the Aggression Resolution is any indication of its future direction, the Court will not only lack coercive power, but over time will squander its opportunity to build a reputation for doing justice and thereby lose its opportunity to gain normative influence.

We share with others both the desire for peace and the abhorrence of war, sentiments that may have originally motivated many of the unjust limitations we have examined. People of good conscience may believe that it is better for victim states to suffer injustice than to forcibly resist aggression and thereby risk a broader and more deadly conflict. However, as we have argued, rules that are perceived as seriously unjust to victims will not encourage compliance with the rules but rather legitimize their violation, resistance, and subversion. Moreover, prohibiting necessary and proportionate defensive force removes deterrents to aggression, advantages unlawful aggressors, and disadvantages their victims. The effect of such a legal regime is to reduce, not increase, the chances of peace, stability, and justice in the world. Those who seek peace at the expense of justice may end up with neither.

\footnotetext{
207 See Part V.A supra.
} 